\title{
RESEARCHING LITIGATION: THE MEDICAL MALPRACTICE EXAMPLE
}

\author{
Thomas B. MetzlofF*
}

\section{INTRODUCTION}

Medical malpractice cases form a distinctive part of the litigation landscape. The simple fact that the defendants are doctors-something of a discrete and insular minority in the litigation world-assures an interested audience as the medical establishment seeks to minimize the impact of litigation on the workings of the profession. As could be expected, the medical profession's view, shared by many others, is harshly critical of the litigation system; members of the profession assert that it is expensive, slow, and unreliable.' This article is intended to focus on the contributions of empirical analysis in understanding how malpractice cases are litigated, primarily by providing an agenda of useful research to be performed."

For at least the past fifteen years, it is clear that the concern with malpractice liability has included a distinctly procedural aspect. In response to the criticisms of the litigation system, some state legislatures have conferred a special status on malpractice cases by enacting a variety of

Copyright 1988 by Law and Contemporary Problems

* Associate Professor of Law. Duke University School of Law.

This article is part of a comprehensive analysis of litigation procedures in medical malpractice cases being undertaken by the Private Adjudication Center. Inc., pursuant to a grant from the Robert Wood Johnson Foundation, whose support is gratefully acknowledged. The opinions or conclusions set forth in this article are those of the author and not necessarily those of the Foundation. Special note must be given to Neil Vidmar, co-principal investigator on the research project, for his many contributions to this paper. Especially in the section on the jury, he essentially served as a co-author, and his assistance is gratefully acknowledged. I also express my appreciation to Paul Carrington. whose creative energies shaped the symposium, and to Randall Bovbjerg. for their helpful readings of the article.

1. These observations do not necessarily serve to distinguish medical malpractice cases from other areas of litigation; complaints have been made for a long time that litigation generally is expensive, slow, and unreliable. Nonetheless, the criticisms draw a measure of support from commentators who typically use malpractice litigation as a prime example of the "litigation crisis." Spe, e.g. J. Lieberman, The Limigious Society 66-94 (1981).

2. Many of these specific concerns are suggested by a research project in which I scrve as a coprincipal investigator. The research, begun in July 1987, seeks to analyze the dynamics of the litigation process as well as to develop efficient means of alternative dispute resolution for malpractice cases. To accomplish these ends, rescarchers are reviewing all medical malpractice cases filed in North Carolina courts over a three-year period, a total sample size of approximately 950 cases. For each case, researchers are reviewing court files to collect data on the nature of the claim and the procedural history of the litigation. A number of preliminary observations are presented in this article. Formal findings should be available in carly 1990. 
procedural changes. ${ }^{3}$ In some instances, these changes have involved supplementing the existing process by imposing new mechanisms, such as the "screening panel" approach enacted in many states in the 1970's in order to discourage the filing of non-meritorious claims. Similarly, some legislatures have enacted legislation to promote arbitration as an alternative to malpractice litigation. Other changes have constituted more of a procedural fine-tuning to correct perceived problems in the current approach. Thus, some states have imposed special pleading requirements in malpractice cases, restructured the discovery process, or limited those able to serve as experts. ${ }^{4}$ Current reform proposals reinforce the procedural critique-the American Medical Association, for example, recently urged replacing the existing system with an alternative set of administrative procedures."

This intensity of concern and activity makes malpractice an important context for reviewing the contribution, both actual and potential, of empirical research in understanding the litigation process. What do we in fact know about the workings of the procedural system in medical malpractice cases? A review of the literature shows that the actual quantum of empirical research is surprisingly sparse. In part, scarcity reflects a lack of empirical analysis generally on the subject of malpractice, ${ }^{\circ}$ but it also results from the inherent difficulties in conducting research on procedural issues. ${ }^{7}$

One problem lies in the difficulty of obtaining detailed and complete information. Medical malpractice cases are litigated predominantly in state courts. Within each state, the cases are geographically allocated among scores of county courts. Thus, to the extent that one begins with court records, reviewing a large number of cases is burdensome. Moreover, no one data source can answer all or even most of the questions presented. In hotly

3. For information generally on the subject of legislative reform in the malpractice arena, including a discussion of procedural changes, see Ackerman, Medical Malpractice: to Time for . More Talk and Less Rheioric, 37 MerCer L. REv. 725 (1986); Robinson, The Medical Malpractice Crisis of the 1970 s: A Retrospective. Law \& Contemp. Probs., Spring 1986, at 5. See generally Gellhorn, Medical Malpraclice Litigation (L.S.) - Medical Mishap Compensation (...Z.), 73 Cornell. L. Rev. 170, $170-77$ (1988).

4. As an example of procedural responses, one could cite the North Carolina General Assembly's recently enacted series of procedural changes requiring greater judicial control over discovery applicable only in medical malpractice cases. Spe 1987 N.C. Sess. Laws, ch. 859.

5. AMA, A Proposed Alternative to the Civil Justice System for Resolving Medical. Llability Disputes: A FaulT-Based, Administrative Sistem (AMA/Specialty Society Medical Liability Project Report, 1988). Other recent proposals have also focused upon procedural reform. See, e.g., Florida ACadfmic Task Force for Revifw of the Insurance. and Tort Systems, Mfedical. MALPRACTICE RECOMMENDATIONS $15-30$ (Nov. 1987) (describing plan for prompt resolution of claims including complex provisions for arbitration, pre-filing investigations, and sanctions).

6. A recent survey of empirical work over the entire range of issues concluded that "/q Juantitative analysts and scholars have thus contributed far less to malpractice debates than have interest groups and professionals applying expert opinion." Zuckerman, Koller \& Bovbjerg, Information on Malpractice: A Rerieu of Empirical Resparch on .Major Policy Issues, I Aw \& Contemp. Probs., Spring 1986, at 85, 110. For a focused discussion of research questions across the range of malpractice issucs, see U.S. Dep't of Health and Human Services, Report of the Task Force on Medical. Liability and Malpractice 179-209 (1987) [hereinafter HHS Report]. Sep generally Bovbjerg, Legislation on Medical Malpractice: Further Developments and a Preliminary Report Card, 22 U.C. Davis I.. Rri. 499 (1989).

7. Sep P. Ebener, Court Efforts to Rriuce Pretrial Dflay 81-82 (1981) (cataloguing difliculties with empirical research in litigation). 
contested cases, court files are replete with information; in other cases, these records are often sparse and unhelpful. Insurance company files-to the extent that the researcher can overcome access problems-are a useful repository of information on the claim and the settlement process, but are less useful on other procedural details. Ultimately, the lawyers' files are most often the best source of data, but concerns of confidentiality and their scattered location limit the researcher's access to that source for any significant number of cases. Even when quality information is available, the time needed to analyze each case is extensive; a moderately complex malpractice case may contain several hundred pages of relevant material.

Another problem is that the focus of most empirical research relating to malpractice has been obscured. On the one hand, some of the relevant empirical work-particularly research on jury performance-has not been focused specifically on malpractice cases, but rather has cut across a wide range of civil litigation contexts. The small number of malpractice cases reviewed makes it difficult to assess the jury's role in resolving malpractice disputes. On the other hand, research on specific malpractice procedures, such as screening panels, has not been adequately related to broader procedural issues.

Another difficulty involves the failure of the system's critics-both researchers and non-researchers alike-to conceptualize and adequately specify the goals of a procedural system. Without such conceptualizations, one lacks a yardstick against which to measure performance. To establish a working framework for analysis, this article begins with the basic assumption that the function of a procedural system is generally to resolve disputes fairly and efficiently. ${ }^{8}$ Fairness and efficiency, however, are relative terms that can be conceptualized on a number of levels and from multiple perspectives." This article's primary concern is with how the procedural system operates in processing specific disputes serving three primary functions. ${ }^{10}$

8. See Fed. R. Civ. P. 1 (rules to be "construed to secure the just, speedy, and inexpensive determination of every action”). Cf. Sibbach v. Wilson \& Co., 312 U.S. 1. 14 (1941) (describing "procedure" as "the judicial process for enforcing rights and duties recognized by substantive law" and for justly administering remedy and redress for disregard or infraction of them").

9. See gemerally E. Lind \& T. Tiler, The Sochal. Psychologr of Procedural Justick (1988); J. Thibaut \& L. Walker, Procedural. Justice (1975). See also Damaska, Structures of tuthority and Comparative Criminal Procedure. 84 Yal. I.J. 483 (1975); Langbein. The German Adranlage in Ciril Procedure. 52 U. Chi. L. Rev. 823 (1985).

10. Certainly, one could articulate the goals differently. For example, the recent report by the Department of Health and Human Services posits eight different objectives relating to the overall workings of the malpractice system. Of these objectives, three relate directly to the litigation process, suggesting that a compensation system should: (1) "resolve claims prompty and in amounts proportional to the injury:" (2) "provide predictable outcomes;" and (3) "operate efficiently in terms of financial costs, professional energies, and governmental processes." HHS REPORT, supra note 6, at 18-19. This article's approach captures most of these elements, although perhaps in a form that is more directly focused upon specific procedural devices and methods.

One element not directly captured by the formulation, but informing all three articulated goals, is the concern with cost itself. Certainly, the high $\cos$ of malpractice litigation is itself a major problem. Sep J. Kakalik \& N. PaCe, Costs and Compensation Paid in Tor' Litigation 55 (1986) (showing that litigation costs for defendants in litigated malpractice cases constituted 29.6\% of the average compensation obtained by plaintiffs); D. YagG \& P. Hodcson, MeidCal Malpractice 21 
The first function is to provide a mechanism or mechanisms for expeditiously handling non-meritorious cases, which if permitted to run the procedural gauntlet could result in significant expense to the parties. The appropriate procedural response to non-meritorious cases can vary. In the past, the motion to dismiss targeted at the sufficiency of the complaint was frequently seen as fulfilling this function. Under the modern approach exhibited by the Federal Rules of Civil Procedure (with similar provisions in force in most states), other mechanisms-most notably the motion for summary judgment or the imposition of sanctions for filing frivolous claimsare more specifically intended to deal with non-meritorious cases. The empirical question is whether these mechanisms work to conclude nonmeritorious cases in a reasonably prompt manner without seriously impacting the assertion of arguably valid claims.

A second function is to provide the parties a structured forum for the voluntary resolution of meritorious claims, that is, settlement. Several aspects of the procedural system are at least indirectly implicated in the settlement process. Certainly, one purpose of the current liberal approach to pretrial discovery is to permit access to information necessary to evaluate a claim. Other procedural innovations, such as grants of authority to the judiciary to conduct pretrial conferences and the growing use of alternative dispute resolution methods, also impact upon settlement practices.

Finally, a third function is to resolve those potentially meritorious cases that are not voluntarily settled. At a minimum, this function requires a method for finding facts and applying relevant law. The desired decisionmaking qualities include competency of the decisionmaker as well as consistency of decisions across cases. Given constitutional commands, the procedural choice is the institution of the jury. Due to its members' lack of expertise, the use of the jury as the predominant means of decisionmaking has raised serious questions as to whether the desired qualities of competence and consistency are attainable.

Viewed within the context of these functions, the purpose of empirical research is not only to describe how the system works, but also to provide evidence to permit an assessment of how well these functions are being fulfilled. This assessment must be made in relative terms; no system can realistically be expected to process disputes perfectly. For example, some non-meritorious cases will not be dismissed expeditiously. Judgments about the efficacy of the system, therefore, require some consideration of the degree

(1987) |hereinafter Private Sector Conference] ("Huge awards are few and far between and often deserved. We are plagued with the high cost of the sustem: the cost of handling claims and attorneys' fees and the burden applied.") (statement of William Ginsburg); HHS REPORT, supra note 6, at 16. Certainly, a claim could be made that minimizing transaction costs should be put forward as a primary goal. Cost, however, is not directly controlled by the procedures offered, but rather by a combination of voluntary and involuntary actions by the attorneys involved. Moreover, a procedural system that fulfills the identified primary functions well would seem by definition to be efficient, regardless of the cost of operation, which would require some benchmark for comparison in any cvent. 
of error or inefficiency that is tolerable, and, equally important, the likely performance of any suggested alternatives.

This article is intended to offer some measure of clarity and, hopefully, imagination on the utility of empirical research in studying the litigation process. The discussion is divided analytically according to the three functions identified above: handling non-meritorious litigation, fostering the settlement process, and resolving cases by jury. Each section begins with a brief sampling of the procedural criticisms or concerns frequently leveled against the current system, followed by a review of relevant empirical studies, and some prescriptions for sharpening the research focus.

\section{II}

\section{Empirical Perspectives on Non-Meritorious Litigation}

A repeated complaint about the litigation system is that it tolerates, indeed perhaps even fosters, non-meritorious litigation. While this argument is often not well focused in terms of identifying which specific features of the procedural system are at fault, the concern is clear enough: Defendants seem to prevail in most malpractice cases, but only after incurring substantial expense and frustration."

In assessing this complaint, one is immediately confronted with a major definitional problem: What is meant by the term non-meritorious litigation?1" Potential nominees could include cases terminated by a variety of procedural methods ranging from a motion to dismiss at the onset of the case to a jury verdict favoring the doctor after a full trial. ${ }^{13}$ Critics tend to equate cases terminated in favor of defendants with those cases being frivolous. Using a

11. See P. Danzon, Medical. Malpractick: Theory, Evidence and Public Policy 18 (1985) (noting "widespread belief that most malpractice claims simply reflect the unrealistic expectations of litigious patients, who sue whenever the results of health care intervention are less than perfect"); J. Guinther, Health Care and the Law II: Patients, Doctors, Lawyfrs \& Jurif.s 5-7 (Papers of the Roscoe Pound Foundation, 1988) (discussion generally of frivolous litigation, with one insurance representative noting that " 60 percent of all the cases alleging malpractice go nowhere, so that means 60 percent of them necdn't have come”); Private Sector Confference, supra note 10, at 17 ("The statistics prelty well show that too many bad cases are brought against physicians.") (statement of Kirk Johnson): Birnbaum, Phwicians Coumlevallack: Liability of Lauyers for Instituting L'inustified . Medical Malpractice Actions, 45 Fordham L. REv. 1003,1004 (1977) ("Many physicians believe that the medical malpractice insurance practice has, in large part, been caused by overzealous and unethical attorneys who institute groundless malpractice suits.").

12. Another definitional challenge would be to attempt to differentiate between frivolous and non-meritorious cases. Logically, it would seem that "frivolous" suggests a subset of nonmeritorious cases focusing on an intentional or reckless decision to assert a claim without regard to available information as to its lack of merit. Beyond that, however, frivolity is probably best understood in terms of the observer's own sensibilities. For present purposes, this article will focus on the existence or non-existence of non-meritorious disputes and the litigation system's responses, leaving the line-drawing as between frivolous and non-meritorious to others.

13. The many possibilities include cases: (1) dismissed pursuant to a motion to dismiss on the ground of jurisdictional defects, bar by statute of limitations, or failure to state a claim upon which relicf can be granted; (2) dismissed pursuant to a motion for summary judgment; (3) dismissed by the plaintiff without prejudice (which indicates no settlement) prior to trial: (4) settled for a nominal amount (a so-called nuisance value settlement); and (5) resolved by the jury returning a verdict for the defendant. 
favorable outcome for the defendant as even a rough proxy for measuring the amount of non-meritorious litigation is inappropriate, however, for at least four reasons.

First, in some instances, a plaintiff's claim may reasonably appear meritorious at the outset only to be revealed as lacking merit as the case evolves over time. For example, a plaintiff's attorney could reasonably believe that the suit was meritorious at the time of filing, only to find out some important fact during discovery that changes the initial evaluation. That the case is then terminated without payment to the plaintiff does not mean that the initial pursuit of the claim was unjustified, although its continuation might be so considered. This point suggests that the challenge faced by the legal system is not merely identifying non-meritorious cases, but rather anticipating the evolutionary nature of the inquiry and intervening at appropriate times.

Second, the fact that a lawsuit is dropped may indicate no more than the fact that the expense of pursuing an otherwise valid claim-perhaps caused by the defendant's obdurance or structural impediments to obtaining qualified expert testimony - has proven to be too much for the plaintiff to bear. ${ }^{14}$ This situation is especially likely to arise if the ultimate recovery, as fully justified as it may be by the physician's negligence, is small. In other cases, the emotional strain of litigation itself may convince a plaintiff to dismiss a potentially valid claim.

A third possibility is that the pro-defendant termination was in error. There are several reasons why potentially meritorious cases may be lost, including failure to develop evidence during discovery; attorney incompetence, inexperience, or poor judgment; judicial bias; inability to obtain competent experts to testify; or simply error by the factfinder.

These first three observations suggest that a study focusing on prodefendant terminations as a measure of non-meritorious litigation is likely to overestimate the phenomenon. The fourth factor cuts in the other direction and suggests that the amount of non-meritorious litigation could be understated. There may well be cases where the plaintiff receives a modest payment in settlement simply because the insurer's assessment of likely defense costs or of the risk of an incorrect decision are sufficiently high to warrant a settlement offer. The existence of such nuisance value settlements is widely postulated. In addition, a non-meritorious case may be pursued through to trial and, owing to jury error, be resolved in favor of the plaintiff. Once again, this possibility is widely suspected.

In combination, these factors establish that focusing solely on the results of cases cannot serve as even a rough measure of the frequency of nonmeritorious litigation. Absent better information about the nature and evolution of the dispute, the presence of significant percentages of case

14. Danzon's observation about the high rate of pro-defendant terminations focuses on this point, noting that the evidence "supports the hypothesis that small malpractice claims are often barred from recovery because of the high fixed costs of participating in the legal process." $P$. Danzon, supma note 11, at 42. 
dispositions favorable to the defendant constitutes mere circumstantial evidence of the existence of a problem. By the same token, however, to acknowledge possibly good or at least neutral reasons for plaintiffs' losing or abandoning claims does not suggest that all is well. Plaintiffs and/or their attorneys, driven by lack of knowledge about the merits of the claim, misshapen expectations, or a desire to coerce a nuisance settlement, may indeed be asserting claims that simply should not be made.

\section{A. Assessing the Potential for Non-Meritorious Litigation: The Closed Claims Study}

Acknowledging this definitional problem permits us to rephrase the initial empirical question: Is there evidence for concluding that there is the potential for a significant amount of non-meritorious litigation? If, in fact, a significant percentage of cases are terminated in favor of physicians, then the effect is to shift the burden to explain or justify that fact. On this point, the data do speak strongly. Existing empirical studies, consisting primarily of closed claims studies, fairly meet this initial threshold of raising a potential concern.

Given that these studies will be discussed throughout the article, it is useful to digress briefly and describe the methodology of closed claims studies. Often conducted by governmental agencies as part of an effort to analyze instability in the malpractice insurance industry, ${ }^{15}$ the closed claims study is designed to collect data on a large number of claims-not just litigated cases-that are terminated during a specified period. ${ }^{1 / i}$ Since many

15. For a general description of the quality of information generally presented in closed claims studies, see Zuckerman, Koller \& Bovbjerg, supra note 6, at 90-91, 97-98.

Methodological problems often present themselves in closed claims studies. A recent effort in North Carolina is instructive. In response to the recent instability in insurance rates for malpractice coverage, the North Carolina General Assembly asked the Department of Insurance to prepare a closed claims study of claims history in North Carolina. Efforts were made to obtain complete records on all closed claims over a three-year period from 1983 to 1986. Despite the interest in obtaining complete information, one of the largest insurers provided detailed information on only half its claims. Nortu Carolina Dep't of Insurance, Medical Malpractice Closed Claims Study, 1983-1986 (1988). In addition, much of the information sought by the Department was unknown to the insurers. For example, the insurers were able to respond to an inquiry about whether the claimant had an cxpert medical witness in only 430 out of 951 claims reported. Id. at 18 app. D (Table 5.6). A third problem was that the information obtained did not always correspond to what had been previously reported by the insurance company in a required annual report. One insurer had previously indicated that it had not closed any claims during the years in question. However, survey data showed that three claims with losses totaling $\$ 1,201,667$ had been closed. Id. at 3 . Cf. Danzon. The Fffects of Tort Reforms on the Frequency and Severity of . Vedical .Valpractice Claims, 48 Oнго ST. L.J. 413, 414 (1987) (noting methodological problems caused by multiplicity of insurers).

16. Data are usually obtained from insurance company files. Complete data are often collected on a subset of claims and then extrapolated to the larger sample. In a U.S. General Accounting Office ("GAO") study, for example, the researchers selected 25 insurers who were willing to cooperate from the total universe of 102 malpractice insurers. The selection was made on a randomized basis among different categories by type of insurer company (private carrier, physicianowned insurer, or hospital-owned insurer). The number of claims closed among this subset of insurers during the year in question totaled over 31,000 . After stratifying these claims according to amount of payment, the GAO randomly selected a varying percentage of claims within cach stratum. Claims were excluded for several reasons. For example, they were excluded where the insurer was involved only as a reinsurer, the file was unavailable, or related files were still open. Approximately 2781 files were randomly selected, of which information was collected on 1706 claims with the 
claims are settled or dropped prior to suit being filed, the universe of claims is significantly broader than litigated cases. This observation is important to keep in mind if one is attempting to assess the workings of the litigation system.

A closed claims study's primary purpose is simply to determine how many malpractice claims were resolved in a given period and the amount paid out by insurers in compensation; the bulk of the information collected concerns variables that do not directly relate to the litigation process. ${ }^{17}$ These summary data are analyzed to describe claim frequency and the amount of payment, if any. The claims data are then cross-tabulated against other variables, such as the nature of the claim. Typically, no effort is made to determine whether medical negligence in fact occurred in a particular case, ${ }^{18}$ or whether the dispute was efficiently handled. In short, the basic point of the closed claims study is to describe who asserted the claim, what injuries were alleged, and how much the claimant received.

Closed claims studies demonstrate that a high percentage of malpractice claims terminate without payment to the plaintiff. Indeed, at first blush, the evidence seems overwhelming. According to the General Accounting Office's ("GAO") recent study of claims closed in 1984, more than half of all malpractice claims closed without payment to the plaintiff. 19 This statistic is generally confirmed by other studies, ${ }^{20}$ but requires explanation. There is no universal definition of a "claim"; claims are not limited to situations in which lawsuits have been filed or even to where the claimant has retained an

remainder being found ineligible for some reason. From this relatively small group. the data were extrapolated to describe 73,500 claims, the total projected number of claims closed in 1984. HumaN Resources Div., U.S. General Accounting Office, Medical. Malpractice: Characteristics of Claims Closed in 1984, at 14-17 (1987) [hereinafter GAO Report].

Earlier studies used a similar approach. See Rudov, Myers \& Mirabella, Medical Malpractice Insurance Claims Files Closed in 1970, in Dep't of Health, Education \& Wfelfare, Rhport of The Secretary's Commission on Medical Malpractice app. at 1, 6 (1973) [hereinafier HEW RePort] (random sample of $20 \%$ of claims from 26 cooperating insurers in universe of 68 insurers, resulting in data collection on 3000 files of which approximately half were used for data analysis).

17. These non-litigation variables generally include: (1) plaintiff characteristics (age, sex, occupation, income, severity of injury, medical expenses incurred, and extent of injury); (2) defendant characteristics (age, specialization. type of practice, educational background, and existence of previous claim); and (3) injury characteristics (place of injury, area of practice involved, severity of injury, and categorization of alleged negligence). GAO REPORT, supra note I6, at 61-73 (copy of data collection instruments used in closed claim study); HEW REPORT, supra note 16, at 22 25 (same).

18. HEW REPorT, supra note 16, at 21 (no effort was made to analyze why the claim was dropped, so that "[t]hese data do not provide any basis for judging malpractice per sc"). The GAO Report attempted to determine whether the level of compensation in cases in which an award was made was adequate at least in relationship to economic damages, although on this ground their findings are admittedly speculative. GAO REPORT, suprn note 16 , at 44.

19. GAO REPORT, supra note 16 , at 19 (indicating that $56.7 \%$ of all claims are terminated without any indemnity payment to the claimant).

20. P. Danzon, supra note 11 , at $32,42(43 \%$ of claims terminated without payment to the plaintiff, with almost two-thirds of these terminations occurring without litigation being filed): J. Mardfin, Medical. Malpractice in the State of Hawail 49.51 (1986) (Table 7) (71\% of claims closed without payment). These results are also tentatively confirmed by our review of litigated cases in North Carolina. At this point, we estimate that approximately $40 \%$ of litigated cases are terminated in defendant's favor prior to trial. 
attorney. Rather, the existence of a claim is defined in terms of the insurer's decision to open a claim file, which may include matters where there has been little objective manifestation of the claimant's interest in pursuing his rights. ${ }^{21}$ The GAO Report provides some further breakdown as to when these claims close. Focusing solely on the non-payment claims, 42.7 percent were closed without litigation ever being filed, suggesting that many were not pursued very far or very hard." $=$ Another 41.9 percent of the non-payment cases were closed after suit was filed but prior to trial, although there is no indication at what stage of the litigation the suit ended or what specific procedural means, if any, prompted the dismissal. 23

Before condemning the system that tolerates such a high level of unsuccessful litigation, it would certainly be useful to analyze any data offering a comparison to other types of litigation. By the same token, the medical profession would be only modestly comforted by the fact that other defendant classes are similarly subjected to high rates of non-prevailing claims. In the absence of comparative data, the level of non-prevailing claims in the malpractice area seems sufficiently high to trigger further search for insights into the causes of as well as the procedural system's response to the observed fact.

Do the existing empirical studies assist us in parsing through the various explanations that might underlie pro-defendant terminations? Unfortunately, they do not. ${ }^{2-4}$ Closed claims studies typically describe nothing more than whether an indemnity payment was made and the general timing of disposition. Since the data are collected from insurance company records, there is little or no explanation from the plaintiff's perspective of what reasons informed the dismissal. Similarly, no known attempt has been made to analyze the insurer's subjective views of the merits of the litigation. ${ }^{25}$

21. GAO RFPORT, supra note 16. at 12. For example, most insurers will open a claim file if notified by the health care provider of an incident, regardless of whether the injured patient had manifested an intent to assert a claim. While the GAO excluded claim files where no demand was ever made, the claim was counted so long as any form of demand was ultimately made.

22. Id. at 82 (Table V.14) (13,544 claims terminated without payment and without suit being filed).

23. Id. The next largest group of claims resolved without pavment were those resolved after trial. An estimated cotal of 1425 claims were resolved after a jury verdict $(4.5 \%)$, while 253 were terminated without payment during the pendency of the trial $(0.8 \%)$. An estimated $733 \mathrm{claims}$ (2.3\%) were terminated following an appeal, apparenty after a trial. Another small group of claims were terminaled in favor of the defendant after being involved in some way within an arbitration system (1456 claims, constituting $4.5 \%)$. The remaining claims were terminated by other mechanisms not described by the GAO.

24. Sep Birnbaum, supra note 11 , at 1006 (noting that with respect to the concern with "frivolous" malpractice litigation that "available statistical data is [sic) unfortunately incomplete and inconclusive since none of the studies undertaken have expressly focused on the problem of unjustified medical malpractice claims").

25. Such an analysis would be possible. Insurers typically perform an investigation of the claim after it is asserted, which may include review by one or more experts. A major purpose of this review is to establish a reserve for insurance accounting purposes of a likely sum that may need to be paid to the plaintiff. While the setting of reserves is not an entirely objective process, it would seem to be a reliable means for analyzing the insurer's assessment of the case. Simply correlating the number of cases in which the insurer established a reserve level other than $\$ 0$ for claims ultimately dismissed in favor of the defendant would provide an important insight into the possible frequency of non- 


\section{B. Explaining and Understanding Non-Meritorious Litigation}

Given that empirical data raise a concern, there is a need to set forth a working hypothesis to explain the observed condition: the existence of a significant proportion of potentially non-meritorious litigation. In light of the different participants in the litigation process, there are any number of possible explanations that might explain the result in a given case. The outcome may be explained in terms of the poor information initially provided to the plaintiff's attorney by either the client or a reviewing expert. Problems in identifying and receiving the cooperation of truly knowledgeable experts may prevent the plaintiff from effectively making his case. The qualifications of the plaintiff's attorney are also directly involved. Did the error in asserting an unsuccessful claim result from the attorney's initial misevaluation or perhaps from the attorney's inexperience in pursuing such claims? Was the case terminated according to plan in that new information was received during the discovery process that reasonably changed the plaintiff's assessment? Is there any indication that the plaintiff's attorney filed a weak case in hopes of obtaining a coerced settlement? Alternatively, was the inherent expense of the litigation process, exacerbated perhaps by the defendant attorney's tactics, a major deterrent to the continued assertion of claims? In any particular case, several of these reasons may combine. Thus, a case may be filed only later to be dismissed because an inexperienced plaintiff's attorney agrees to file a marginal claim, is unable to locate sufficiently compelling experts, and then decides to drop the suit.

To a large degree, improving our understanding of the non-meritorious litigation will require far more study of the plaintiff's side of the equation, including a focus on both the plaintiff and the plaintiff's counsel. To date, the bulk of the research has proceeded based upon summary data from insurers. Such data, while certainly useful, are not likely to provide meaningful insight into the dynamics of the case development from the plaintiff's perspective. Most of the concerns in the area of frivolous litigation center on the plaintiff's side of the dispute: the attorney's initial evaluation of the claim, the continuing assessment of the merits of the case, and the process of locating experts for analysis or presentation of the dispute. Without analyzing the plaintiff's perspective, even if only to describe case dynamics in a representative sample of cases, it is unlikely that a study of potentially nonmeritorious litigation could get very far.

1. Focusing on the Party Plaintiff. In attempting a deeper understanding of the nature of malpractice claims, a useful tack would be to analyze typical patterns of patient behavior generating malpractice claims. Is there something about modern medical practice that causes a significant number of non-meritorious claims? For example, we might expect a large number of non-meritorious claims in the employment discrimination area by plaintiffs

meritorious litigation. For the best analysis to date bearing on the issue, see H. GENN, Hard Bargaining: Out of Court Settlement in Personal. Injury Actions (1987). 
who are poor judges of their own work. What similar dynamic may explain a high level of false hopes in the medical context?

While there has been a growing focus on plaintiff expectations and the litigation process, ${ }^{26}$ only limited work has been performed in the malpractice context. Existing studies establish that only a small percentage of potential claimants ever assert a claim. ${ }^{27}$ The reasons why some disgruntled patients sue while others elect not to may suggest a possible cause of non-meritorious claims.

A study by May and DeMarco suggests some potentially significant insights on this point." ${ }^{28}$ A series of interviews of clients claiming to have problems with their doctors revealed that the bulk of the problems related to technical concerns with work performed, while doctor insensitivity was the second major cause. ${ }^{2}$ The usual response to the problem was to find another doctor; the second most frequent was to do nothing. Resort to an attorney was an unusual response in that only 11.4 percent of the sample of clients with problems consulted a lawyer. ${ }^{30}$ Based upon the existing data, the authors of the study were unable to draw any clear relationship between the type of problem and the likely response to it. Indeed, even for the small percentage of patients who consulted an attorney, there was little correlation with the type of dispute involved. One possible observation is that personal factorssuch as the doctor's method of communicating or dealing with the patientare as important in whether the patient seeks access to the legal system as the patient's lay assessment of whether medical negligence occurred. ${ }^{31}$

26. There is a developing body of theoretical and empirical literature bearing on why injured parties do or do not pursue grievances. See, e.g. K. Bumillek, The Civil. Rights Society: The Social Construction of Victims (1988); L. Friedman, Total Justice (1987); A. Hirschman, Exitr, Voice, and Loyalty: Responses to Decline in Firms, Organizations, and States (1970); Engle, The Ouerbird ss Song: Insiders, Outsiders and Personal Injwies in an Imeviran Community, 18 LAW \& SoC'Y Rev. 551 (1984); Felstiner, Abel \& Sarat, The Emergence and Transformation of Disputes: . Vaming. Blaming, and Claiming, 15 Law \& Soc'y Rev. 631 (1981); Merry \& Silbey, What do Plaimliffs llamt? Rexamining the Concept of Dispute, 9 Just. SY's. J. 151 (1984); Miller \& Sarat, Griezances, Claims, and Dispules: Assessing the Adversary Culture, 15 Law \& SoC'y Rev. 525 (1981); Vidmar, Justice. Motives and Other Psychological Factors in the Development and Resolution of Disputes, in The Justice Motive in Social Behavior 395 (M. Lerner \& S. Lerner eds. 1981); Vidmar \& Schuller, Individual Differences and the Pursuit of Legal Rights, 11 LAw \& Hum. Behav. 299 (1987).

27. Sep California Medical Ass'n and California Hospital Ass'n, Report on the Medical. Insurance Feasibiliry Study (D. Mills ed. 1977); cf. Pocincki, Dogger \& Schwart\%, The Incidence of latrogemic Injuries, in HEW REPORT, supra note 16, at 50 (extrapolating that in a given year there would be a total of 517 injuries caused by negligence in the hospitals involved, resulting in 31 malpractice claims). The number of observed negligence cases and asserted claims was quite small in these studies. Neither study provides any insight into why some of those injured choose to assert a claim. Current research being conducted by the Harvard Medical Practice Study may shed considerable light on the process of claiming in malpractice cases. See Hiatt, Barnes, Brennan, Laird, Lawthers, Leape, Localio, Newhouse, Peterson, Thorpe, Weiler \& Johnson, A Study of Medical Injuy and Medical . Valpractice, 321 NEW ENG. J. MED. 480 (1989).

28. M. May \& L. DeMarco, Patients and Doctors Disputing: Patients Complaints and What They Do About Them (1986).

29. Id. at Table $2(55.6 \%$ technical failures; $30.5 \%$ insensitivity; $13.9 \%$ communication problems).

30. Id. at Table 1.

31. Some cases probably result from the injured parties' emotional needs to cope with the grief of major injury or death to themselves or to loved ones. Sep T. Rando, Grief, Dying, and DFatu: 
2. Analyzing the Role of the Plaintiff's Attorney. Another factor in understanding the genesis of non-meritorious claims is the role of attorney competence and expertise in the assertion and processing of claims. To date, no research has been undertaken to analyze the effect of attorney specialization in the area of malpractice. It has been observed that most malpractice cases are sufficiently complex that a plaintiff has no realistic opportunity for success without an attorney. ${ }^{32}$ Beyond this observation, however, no empirical studies have been done to analyze the effect of attorney experience on litigation outcomes in malpractice cases. ${ }^{33}$ As a first cut, simply knowing the degree of specialization-especially in terms of representing plaintiffs ${ }^{34}$ - would be important. In addition, account must be taken of the referral practices of attorneys to assess whether inexperienced lawyers associate with more experienced attorneys who assist in the handling of disputes. ${ }^{35}$ Ultimately, the goal would be to analyze whether experienced malpractice attorneys handled cases differently than those less experienced, and the degree to which experience explains variations in outcomes.

If research studies indicated that experienced malpractice attorneys handled cases better than their inexperienced counterparts, the consequences could be profound. ${ }^{36}$ If major inefficiencies in the litigation process-such as the filing of non-meritorious litigation-could be traced to inexperienced plaintiff's attorneys, several reforms are suggested. Certainly, states debating

Clinical Interventions for Caregivers (1984); K. Smith, Stages of Sorrow (1978). Dealing with grief can sometimes involve taking action (such as filing a malpractice claim) or attempting to transfer guilt (again perhaps by blaming the doctor).

32. P. DAnzon, supra note 11 , at 44. Danzon also notes that perhaps the best predictor of higher claim frequency and severity is urbanization. $I d$. at 74 . While partially explained by medical specialization in urban areas, other factors are at work, including higher verdicts in urban courts. One explanation not directly tested by Danzon is the increased ability of attorneys in urban areas to concentrate their practice. Thus, the impact of attorney specialization is potentially of major interest.

33. For an overview of research on specialization in the legal profession generally, see O. MARU, Researci on The Legal Profession: A Review of Work Done 22-24 (2d. ed. 1986) (noting that "there is no foundation of facts on which to build because specialization as such has not been seriously studied").

34. The issue is primarily one relating to the representation of plaintiffs. Defense of malpractice suits is controlled, either by way of contractual right or through practice, by insurers who regularly employ a relatively small cadre of attorneys to defend their cases. While knowing the precise degree of concentration on the defense side would be useful, it is likely that the bulk of attorneys on the defense side will be experienced malpractice attorneys under any definition. The vagaries of the process of retaining plaintiff's counsel are such, however, that there is considerable opportunity for the novice malpractice attorney to become involved.

35. See generally Spurr, Referral Practices Among Lateyers: A Theoretical and Empirical Analysis, 13 LAw \& SOC. INQUIRY 87 (1988) (suggesting that referral practices work efficiently to channel cases of greater value to more qualified attorneys).

36. This is not to suggest that experience necessarily is good. An alternative hypothesis is that the experienced malpractice lawyers may eventually seek to limit their practice to malpractice cases, thus creating a constant need to have a set number of cases in order to keep busy. As such, given the need to process claims, they may file claims that objectively are lacking in merit in order to keep them and their staff working. Familiarity may also create different incentive structures which affect the settlement dynamic. An experienced attorney, faced with a refusal by an insurer to make a settlement offer, may feel compelled to try the case in order to maintain credibility for future settlement negotiations, whereas an inexperienced attorney, not expecting future dealings, might abort a weak case. 
the merits of proposals for specialization programs might find the information useful. Educational programs designed to convey the requisite experiential knowledge could be developed, or certification programs for malpractice lawyers could be considered. Private marketing efforts involving claims of specialization could be encouraged. Courts could even consider limiting malpractice litigation to experienced lawyers or at least requiring that an experienced lawyer be retained as co-counsel.

Given the clear benefits of analyzing the experience factor in malpractice litigation, why have researchers ignored it? Obtaining information on specialization in the legal profession is difficult-there is no easily accessible and reliable list of experienced plaintiff's malpractice lawyers. Until recently, states did not permit public claims of expertise or specialization by attorneys in any field, despite the reality of specialization. 37 While some states now sponsor certification programs in some areas, ${ }^{38}$ no state has a certification procedure for medical malpractice expertise. Self-defined labels of expertise continue to be prohibited by most states, ${ }^{39}$ and efforts by private groups to qualify expertise are also restricted.40 Given this complex of legal and ethical entanglements, a researcher is left to create an independent objective measure of expertise, perhaps defined in terms of the number of malpractice

37. See generally J. Heinz \& E. Iaumann. Chicago Lawyers: The Social. Structure of The Bar (1982) (noting that $70 \%$ of attorneys claim to specialize).

38. The most common approach has been to have the state establish a small number of specialty areas and then administer a credentialing process complete with testing and educational requirements. To date, relatively few states have established such programs, and the areas of specialization are limited and in themselves somewhat generic. For example, California's specialization program, begun in 1971 , allows attorneys to go through a rather rigid examination and educational process in order to claim specialization in a number of areas such as criminal law, tax law, or family law. C. Wolfram, Modern Legal. EThics 204-05 (1988). A few states have programs that include a specialty area for civil litigation. but none have defined a more specific category that would include medical malpractice. Other states have adopted self-designation programs that permit attorneys to market themselves as specializing in certain limited fields upon minimal proof of substantial experience in the field, along with some degree of continuing education. Sep Davidson, The Florida Designation Plan: A Practical tpproarh to Legal Specialization, 30 BAyuor L. Rev. 701 (1978).

Despite states efforts to structure the process otherwise, numerous legal malpractice cases suggest that there is relevant expertise in the area of handling medical malpractice claims. See, e.g. . Togstadt v. Vesely, Otlo, Miller \& Keefe, 291 N.W.2d 686 (Minn. 1980): Procanik v. Cillo, 206 N.J. Super. 270, 502 A.2d 94 (1985), reid, 543 A.2d 985 (N.J. Super. Cl. App. Div. 1988).

39. Sep Moder. Rules of Professional Conduct Rule 7.4 (1983) (permiting an attorney 10 communicate ficlds of practice, but prohibiting an attorney from stating or implying that he or she is a specialist except for patent lawyers, admiralty lawvers, or other areas designated by the particular state).

40. See In re Peel, 126 Ill. 2d 397. 534 N.E.2d 980, cent. granted sub. nom. Peel v. Attorney Registration and Disciplinary Comm'n, 109 S.Ct. 3240 (1989). See generally In re Amendments to the Code of Professional Responsibility and Canons of Judicial Ethics, 276 Ark. 600, 604-05, 637 S.W.2d 589,592 (1982) (refusing to certify attorneys as specialists who had been so designated by the National Board of Trial Advocacy despite the fact that the NBTA's criteria were "at least equal and probably more stringent" than the state bar's criteria). Cf. Johnson v. Director of Professional Responsibility, 341 N.W.2d 282 (Minn. 1983) (permitting attorney to use certification by National Board of Trial Advocacy as a "Civil Trial Specialist" owing to the state's failure to promulgate rules to implement its own specialization system). Thus, the situation is quite unlike the extensive private credentialing process in medicine. See Havighurst \& King, Prizate Credentialing of Heallh Care Persomel: All tntimust Perspective, (Pant One). 9 Aм. J. L. \& MEv. 131. 138-150 (1983). 
claims or cases handled over a certain period of time, a difficult statistic to obtain.

\section{The Responsiveness of the Litigation System in Identifying and Dispensing with Non-Meritorious Litigation}

Focusing on the reasons why some patients sue and the role of attorneys in the process would provide important insights into the question of nonmeritorious litigation. In addition, there is a need to focus substantial research energies on the responsiveness of the procedural system itself. The concern with non-meritorious litigation is not simply its existence or its causes, but how the system responds to it. As already mentioned, no system can be designed that would preclude the assertion of non-meritorious claims. The litigation system anticipates non-meritorious litigation and provides procedural devices to terminate such cases. Indeed, several procedural devices are potentially involved in stemming the tide. In an era increasingly dominated by a sanctions mentality, attempting to identify and punish inappropriate behavior by plaintiffs or their attorneys for filing frivolous suits is a potential procedural response. ${ }^{41}$ Nonetheless, the most significant procedural means available to handle non-meritorious litigation is probably the motion for summary judgment. In the medical malpractice context, attention must also be focused on the performance of the screening panel procedures in identifying non-meritorious cases.

1. Evaluating the Utility of Summary Judgment. Summary judgment is a wellrecognized procedural tool that has been available, essentially in its present form, for an extensive period of time. Empirical research on summary judgment is limited, but suggests that relatively few cases are terminated by

41. It is interesting to note that a significant portion of the recent development of state procedural law concerning sanctions and frivolous litigation. including developments in the tort of malicious prosecution, has occurred in the medical malpractice context. See generally Birnbaum, supra note 11, at 1077-89. Cf. S. Law \& S. Polan, Pain and Profit: The Politics of Malpractice 86, 267 n.86 (1978) (noting that numerous state medical societies assisted in financing countersuits against plaintiff's attorneys). Recently, a jury in Georgia awarded a doctor $\$ 135,000$ for being the victim of malicious litigation under the doctrine enunciated in Yost v. Torok, 256 Ga. 92, 344 S.E.2d 414 (1986). See Fulton County Daily Report, Dec. 16, 1988, at 2.

Many states, following the lead of the federal courts, have adopted a revised version of Rule 11 which now requires an attorney to have an objective basis for asserting a position in any paper filed in court. See Fed. R. Civ. P. 11. Empirical research on Rule 11, which was amended in 1983, is still in its infancy. See Kassin, An Empirical Study of Rule 11 Sanctions (1985). The adoption of state counterparts to Rule 11 is even more recent; in North Carolina, for example, the amended Rule 11 was effective only as of January 1, 1987. N.C. GEN. STAT. \$ 1A-1, Rule 11 (1988). Given how recently the change has taken place in most states, it would not yet be productive to analyze the impact of the amended rule on the assertion of malpractice claims. 
the process, ${ }^{42}$ although the rate at which summary judgment motions are filed and granted varies considerably among different case types. ${ }^{43}$

A profile of the use of summary judgment in malpractice cases would be useful. ${ }^{4+}$ An adequate profile would include a breakdown of the different purposes that a summary judgment motion could address. Some motions, for example, seek only to extricate a peripheral defendant in a multi-defendant suit. Other motions raise legal challenges. Perhaps the most significant motions, however, are those that seek to challenge the assertion of negligence on the part of all or at least the primary defendants in the case. Knowing the success rate for summary judgment motions across the board would not be nearly as valuable as knowing the results within these different categories.

Beyond mere description, however, empirical research could contribute to a more refined understanding of the role of the summary judgment process. Existing studies confirm that a significant proportion of summary judgment motions are never acted on by the court. ${ }^{45}$ Explaining the impact of these non-decisions in response to the motions is vital. It may be that the filing of the motion itself serves to convince plaintiffs to dismiss their case;

42. The most recent empirical study indicates that approximately $6 \%$ of federal court cases are terminated pursuant to grant of a summary judgment motion. J. Cecil \& C. Douglas, Summary Judgment Practice in Three District Courts (1987). See Mclauchlan, in Empirical Study of the Federal Summary Judgment Rule, 6 J. Legal Stud. 427, 449-54 (1977) (review of filings in onc district court indicated that summary judgment motions were filed in only $4.0 \%$ of all cases, resulting in disposition in $2.3 \%$ of total filings)

These studies are descriptive, and do not purport to assess whether summary judgment provides an adequate filter for non-meritorious cases. The study by Cecil and Douglas, for example, involved a review of approximately 200 terminated cases in each of three different federal district courts. I. Cecil \& C. Dougias, supra, at 3. Given the nature of the federal court docket, few, if any, malpractice cases were involved.

43. Cecil and Douglas indicated that summary judgments were routinely filed in social security cases, owing to the administrative proceeding occurring prior to the filing of the lawsuit. J. Cecil \& C. Douglas, supro note 42, at 3-4. Summary judgments were filed in $30 \%$ and $20 \%$ respectively of the civil rights and prisoner cases in the sample. Id. at 7 . These high numbers tend to confirm the perception that the potential for non-meritorious cases in these litigation contexts is high. In personal injury actions, summary judgments were filed in only $11 \%$ of the cases. $I d$.

44. One of the few detailed discussions of the use of summary judgment in medical malpractice cases is found in Brunet, The L'se and . Wisuse of Expert Testing in Summany Judgmemt, 22 U.C. DAVIS I. REV. 93 (1988). One study provides a glimpse into the frequency of use of summary judgment in malpractice cases. The National Center for State Courts' review of Arizona's screening panel collected some background data on the court system. In the vear prior to the introduction of the screening panel, 18 out of 139 malpractice cases (13\%) were terminated by a grant of summary judgment. National Center for State Courts, Medical liability Review Panfis in Arizona: An Evaluation 13 (1980). No data are presented on how often the parties moved for summary judgment or other dispositions. Preliminary data from our research suggest that in North Carolina the rate of filing in malpractice cases is relatively high, with such motions being filed in over onequarter of all cases. The overwhelming percentage are filed by defendants. The data indicate that filing of the motion is often effective in terminating the dispute. While only a modest proportion are granted outright, in a significant percentage of cases the filing of the motion serves as an impetus to the plaintiff to dismiss its case. Of course, success is a relative term and must be assessed in terms of how long it took to obtain the dismissal of the case, the cost, and the appropriateness of the final disposition.

45. According to Cecil and Douglas, 34\% of all summary judgment motions in the federal court sample were never acted upon. J. Cecil \& C. Douglas, supra note 42, at 6 . While not providing a relative breakdown, the report notes that the non-decisions represented either settements following the fling of the motion or dismissals by the plaintiff. 
alternatively, the filing of the motion could spur meaningful settlement negotiations by encouraging a recalcitrant plaintiff or defendant to return to the bargaining table with more realistic expectations. Even if only a small proportion of summary judgment motions were granted, the existence of the procedure could nonetheless serve as a useful adjunct to either the settlement process or the existing mechanisms for the removal of non-meritorious cases, apart from any direct judicial involvement.

\section{The Screening Panel and Non-Meritorious Litigation. The potentiality of} procedural mechanisms to identify non-meritorious litigation can also be assessed by reviewing the performance of specialized panels created in numerous states in the mid-1970's to review malpractice claims prior to litigation. ${ }^{46}$ The panels operated differently among the various states, ${ }^{47}$ but they typically required plaintiffs to submit their claims to a panel consisting of three members, at least one of whom would be a doctor. The panel would evaluate the evidence and issue a determination as to whether the claim had merit, and, in some states, suggest a damages award if liability were found.

One of the panel's primary purposes was to identify frivolous cases at an early stage in the process. ${ }^{48}$ Theoretically, a determination of "no liability"

46. Some form or variety of screening panel was enacted in over 30 states. Sep Human Resources Div, U.S. General Accounting Officf, Medical. Malpractice: No Agreement on the Problems or Solutions 133-39 (1986).

47. The screening panels in the states that have implemented them differ in important respects, including: (1) whether the procedure is mandatory or voluntary; (2) whether screening must precede the filing of the suit; (3) whether the panels are empowered to make an award of damages: (4) the number of panel members to hear a case; (5) the qualifications of panel members; (6) the selection mechanism for panel members; (7) use of experts; (8) use of the panel's determination in subsequent litigation; and (9) the formality of the hearing itself. Sep P. EBener, supra note 7, at 56-68. It is important to take cognizance of these many differences because they limit one's ability to generalize an individual state's performance with a particular screening panel procedure to the collective whole. It is also important to note that screening pancls are usually adopted as part of a package of substantive reforms intended to address perceived problems in malpractice litigation. These other contemporaneous changes in the legal system also serve to complicate any analysis of the screening pancl's impact on the litigation system due to the confounding effects of these other changes.

48. See. e.g., Daughtrey \& Smith, Medical Malpractice Rerieu' Panels in Operation in I'irgimia, 19 U. Ricir. L. RFv. 273, 275 (1985) (" $\mid$ a| major goal of the legislation is to help contain the cost of medical malpractice insurance by encouraging . . abandonments of non-meritorious claims"). Screening panels were also intended to achieve other goals including early setulements of meritorious claims. See infra text accompanying notes 72-80. The panels also were intended to speed the disposition of claims. Unburdened by docket demands created by other cases and by the ability to proceed informally, they could process claims more efficiently, with an attendant reduction in transaction costs. This latter purpose was clearly not achieved in all cases. Sep, e.g., Mattos v. Thompson, $491 \mathrm{~Pa} .385,421$ A.2d 190 (1980) (declaring screening panel provision unconstitutional due to the delay, often as long as four years, in having a hearing scheduled); Howard, An Evaluation of . Vedical Liability Revieu Panels in Arizona, Srate Cr. J., Spring 1981, at 19 (noting delay with appointing and convening malpracice panels in Arizona).

In addition, it was intended that the panels would lower expenses. The evidence on this point is mixed. Frank Sloan reviewed insurance premium information and attempted to correlate changes in premium rates for malpractice insurance over the period 1974-78 with a number of different tort reform proposals enacted by the particular states. One variable was the existence or non-existence of a screening panel procedure. While not attempting to assess the performance of screcning panels, the analysis noted that over this particular period of time, there was a statistically significant corrclation between the existence of screening panels and a reduction in premiums; indeed, this was the only variable that consistently correlated with a reduction in premiums. Nonetheless, Sloan 
would discourage pursuit of the claim. What impact have the screening panels had, or put differently, what insights into the existence or handling of frivolous litigation has the screening panel experience provided? The studies have established that in a high percentage of cases, findings of "no liability" by the panel result in the claim being dropped without litigation being filed. 49 Some of these studies have taken this fact and concluded-rather cavalierly at best-that screening panels have worked to screen out frivolous claims. ${ }^{50}$ Absent comparative insight into whether these claims would in fact have been asserted in court in the absence of a panel procedure, the conclusions drawn are questionable. None of the studies discussed in the report involved prepanel baseline data against which panel performance could be assessed; nor did the studies control for other variables that could explain observed outcomes. Citing high disposition rates without significant subsequent litigation ignores the fact that the panel system may identify claims that would otherwise never come to the attention of medical insurers or the legal system, absent the mechanism itself. The screening panel may well have encouraged parties to abandon any private screening (usually by plaintiff's lawyers) in favor of the free screening provided by the panel. Moreover, even in the absence of screening panels, a significant percentage of litigated cases are dropped with minimal expense to the defendant. Without a comparative assessment of costs or other relevant concerns, there may be no reason to prefer screening panels. Finally, there remains the fundamental question whether the panel determinations are correct. Recent evidence from Hawaii indicates that a number of claims involving "no liability" findings by the panel are in fact pursued by plaintiffs to a successful end. 51

A series of studies of the Arizona screening panel52 represent the only research to date with a methodological design adequate to permit meaningful

points out that there is reason to question the long-run impact of screening panels on premiums. given the potential for added expense in cases that do not require further proceedings, as well as the possible encouragement of more claims owing to the existence of the informal procedure. Sloan. State Responses to the Malpractice Insurance "Crisis" of the 1970s: An Empirical Assessment. 9J. Healti Pol. PoL'y \& I. 629, 636, 640-43 (1985)

49. The major work here is a compilation of carly returns from numerous state screening panels prepared by the Intergovernmental Health Project in 1980. This report noted that panels had achieved significant records of promoting early terminations in numerous states. P. CARLIN, Mrdical Malpractice Pre-Trial. Screening Panels: A Review of The Evidence $30-32$ (1980) (noting both high level of findings in favor of defendant physicians and low rate of subsequent litigation). Other studies make the same point for individual states' experiences. See. e.g., Daughtrey \& Smith, supra note 48 , at 289 (noting that more than two-thirds of claimants did not pursue claim following screening panel's finding of non-liability).

50. See P. Carlin, supra note 49, at 30 ("high correlation between a panel's decision and the final disposition of the case may indicate, at least in some of the states, that scrcening panels are effectively weeding out a number of unjustified claims"); Dance, Medical Malpractice: Prelitigation Screening Panels in Idaho, 19 IDAHO L. Rev. 31, 45 (1983) (system is "successful and worthwhile" because, based on a survey of law firms, only $26 \%$ of cases found to be "without merit" were later filed in court, thus suggesting that lawsuits were kept from being filed in the remaining $74 \%$ of cases "without merit").

51. See infra text accompanving notes 75-78.

52. The Arizona experience was initially evaluated by the National Center for State Courts. National. Center for State Courts, supha note 44. Their findings are summarized in Howard, supra note 48. Sep also Note. At Practical Assessment of Arizona 's . Medical Malpractice Srreening Sistem. 1984 ArIz. 
analysis of the panel's performance. Data were collected on malpractice claims before and after implementation of the panel system in 1976. The data included information from two major malpractice insurers regarding expenses charged to various files, which consisted primarily of outside counsel legal fees. These data serve as a useful proxy for litigation costs to defendants, a potentially important factor in assessing any litigation system's handling of non-meritorious litigation.

The data produced a number of interesting findings relating to an understanding of frivolous litigation. The panels had no significant effect on the proportion of cases that involved indemnity payments or on the amount of indemnity payments. Claim frequency, however, increased significantly-a rather disturbing finding given the goals of reducing litigation by removing non-meritorious cases. ${ }^{53}$

The authors of the study hypothesized that one of the reasons that more cases were coming into the system was that plaintiffs who previously would have been deterred by private screening and discovery costs could now afford to pursue claims under the panel system. This does not necessarily mean that more cases are being encouraged; it could mean only that they have become visible under the panel system. Further, to the extent that this alternative hypothesis is true, it might affect the conclusion that there was no significant effect on the proportion of indemnity payments: Indeed, the proportion could be lower if the panels are screening more non-meritorious cases than would have entered the system.

In sum, empirical researchers face a major challenge in both identifying the extent of potentially non-meritorious litigation and describing how the litigation system has reacted to it. While additional research initiatives could shed much-needed light on the existence of the problem and perhaps suggest some solutions, the challenge of quantifying the number of non-meritorious claims remains. The problem of piercing through the fog generated by incomplete information from a variety of sources may well prevent the researcher from ever being able to isolate the hopeless case, leaving us to study the issue through indirect means.

III

\section{The Settlement Process}

Existing empirical work has sounded one clear note: As with other types of litigation, voluntary settlements ${ }^{5+}$ constitute the predominant method of resolving malpractice cases. As many as 90 percent of the claims in which

ST. L.J. 335. Shmanske and Stevens prepared a further analysis drawing upon the existing data base. Shmanske \& Stevens, The Performance of Medical Malpractice Revieil Pamels. 11 J. Health Pol.. POL'Y \& L. $525(1986)$.

53. Sep Shmanske \& Stevens, supra note 52, at 529-33.

54. As used in this article, a seulement is a voluntary resolution in which the defendant agrees to make a payment (o) the plaintiff in return for dismissing the claim. The term is occasionally used more broadly to refer to the resolution of the dispute by any means and regardless of whether the plaintill reccived any compensation. Sep GAO REPORT, supra note 16. app. V at 82 (Table V.14) 
payment is made to the plaintiff are resolved without an adjudicative proceeding, that is, without arbitration or trial. ${ }^{55}$ This fact alone justifies significant research into typical settlement patterns. Unless one understands the dynamics by which most disputes are removed from the system, one cannot fully assess its workings when it does in fact determine the merits of a case; an aberrant trial result may be tempered by evidence of an efficient extra-judicial system.

Ironically, the settlement process has not often served as a focal point of criticism among malpractice observers. If the current system is bad, the settlement process must be at least partially at fault given its tremendous level of involvement. The lack of direct criticism reflects the fact that settlement, occurring outside the public eye, is not well understood. By the same token, however, many of the criticisms directed elsewhere have settlement applications. Concerns with biased juries, high transaction costs, and the existence of large amounts of frivolous litigation combine to suggest that the prevailing procedures may coerce defendants to settle weak cases or pay more than the fair amount in meritorious cases given the expense and risks associated with attempting vindication. Moreover, even in those cases in which reasonable settlements are obtained, it may be that it took too long or cost too much to resolve the dispute. ${ }^{56}$ Accordingly, a focused criticism of the settlement process in malpractice cases would include concern with what Galanter has recently called the "quality" of settlements. ${ }^{57}$

\section{A. The Interaction between Litigation Procedures and the Settlement Process}

We know little about the settlement process in malpractice cases. Acknowledging the overwhelming fact that many settlements occur is hardly descriptive of the process. Empirical research, consisting primarily of closed claims studies, provides only general guidance as to when cases settle or what events tend to trigger voluntary agreement. ${ }^{5 x}$ By far the largest category of settlements-approximately 60 percent of the total cases settled-occur after

(reference to the universe of possible dispositions as "settlement stages" so that a trial or arbitration would be considered a setulement stage).

55. According to the recent GAO Report, terminations in the plaintiff's favor (with a pavment) occurred in 24,630 claims at the following stages: (1) prior to the filing of a lawsuit (7562 claims or $30.7 \%$ of all claims closed with a pavment); (2) after filing of the suit but before trial (15,252 or $61.9 \%$ ); (3) during trial $(585$ or $2.4 \%)$; (4) after trial is completed (331 claims or $1.3 \%)$; (5) after appeal (277 claims or $1.1 \%) ;(6)$ as part of the arbitration process (370 claims or $1.5 \%)$; and (7) other scenarios (253 claims or $1.0 \%$ ). GAO RtPorT, supra note 16 , app. $V$ at 82 (Table V.14). The first two categories-the non-trial settements-total approximately $93 \%$ of all plaintiff recoveries. See HEW REPORT, supra note 16 , at 14 (Table 2 showing that plaintiff obtained some recovery in $40.0 \%$ of the cases, and of this group, $90.3 \%$ of the settlements were resolved prior to (rial).

56. This point reflects the general concern with the ad hoc process by which settlements are usually oblained. See W. Brazh. Setting Civil. Surrs 44 (1985) (process of obtaining settlement is "awkward, expensive, time-consuming, and stressful").

57. Galanter, The Quality of Seltlements, 1988 Mo. J. Disp. Resolution 55.

58. Some limited eflorts have been made to model the negotiating process through the use of cconomeric models. Sep P. Danzon \& L. I lillard, Tile Resolution of Medical. Malpractice. Claims: Modfing, the Bargaining Process (1983). 
litigation is filed but before trial. ${ }^{59}$ Some of these cases settle soon after the case is filed, while others practically settle on the courthouse steps as the trial is about to start. Closed claims studies are content to lump these potentially disparate situations into a single category. But the differences between them in terms of expense to the parties and often to the judicial system, the information upon which the settlement was based, the reasons for accepting the settlement, and how the agreement was negotiated, are potentially quite significant.

A contribution to our understanding of settlement could be made simply by describing the timing of settlements with greater precision. The mass of pretrial settlements needs to be broken down into meaningful subsets. One approach would be to focus more descriptive energies on the chronologies of cases, from the time of filing the complaint to the date of settlement. A more refined approach would relate the settlement to the procedural status of a case. Many of the procedural rules available within the litigation process have the potential to shape or affect settlement. For example, the filing of a summary judgment motion by the defendant, even if not likely to be granted, serves to impose costs on the plaintiff which may well affect settlement decisions. Other procedural matters-such as whether to bifurcate the issue of damages and liability or sever a defendant for a separate trial-materially affect the dynamics of the settlement process. An attempt to correlate settlement patterns with procedural events would enhance our understanding of the relationship of the procedural system to the settlement process.

This point can be illustrated by considering the potential relationship between settlement and the discovery process. How many cases settle with only minimal use of the discovery tools available? Put differently, to what degree are settlements driven by specific events occurring during discovery or in conjunction with the discovery process? Likely candidates for empirical scrutiny include the influences of the depositions of key individuals (the defendant, the plaintiff, and the parties' respective expert witnesses), or judicial rulings on discovery motions. For example, if the parties are seldom in a position to assess settlement of the case until such time as the opposing parties' trial experts are scrutinized, this fact will have significant ramifications for efforts to streamline the process.

\section{B. The Quality of Settlements in Malpractice Cases}

As a second major area of research opportunity, there is a need to explore the quality of malpractice settlements in greater detail. Particularly, researchers must go behind the fact of settlement to analyze the positions and justifications offered by the respective parties to determine the applicable range of normative concerns..$^{(i)}$ Negotiation is often justified as the preferred means of resolving disputes because it permits the litigants to resort to a

59. GAO REPORT, supra note 16 , app. $V$ at 82.

60. Galanter, supia note 57 , at $75-78$. 
broader spectrum of norms. ${ }^{61}$ Yet it is likely that the negotiating environment differs significantly among dispute contexts. While there is some evidence that mechanistic settlement rules develop in routine cases, ${ }^{62}$ results in more complex disputes are more a product of the attorneys' skills across a range of factors. ${ }^{63}$ The ultimate challenge of empirical research on the litigation dynamic in malpractice cases may well be in describing the operative norms of the negotiating environment.

The negotiating environment could be profitably explored in connection with an analysis of the substantial number of claims settled without a lawsuit being filed at all. A full third of claims in which the plaintiff receives compensation are settled without a lawsuit being filed. ${ }^{64}$ The existence of such a large cohort of disputes being resolved expeditiously without any direct judicial involvement is at least curious. To understand the potential importance of these pre-litigation settlements, we must start by describing the nature of the claims-in terms of complexity, factual issues presented, and damages claimed-and compare this profile to the claims that are litigated. Two opposing scenarios are suggested. In the first, the insurer may simply be settling the smaller cases-those where a few thousand dollars will placate the plaintiff without involving defense attorneys at all. This appears to be the prevailing assumption and has empirical support at least for insurers' settlement practices in the 1970's. ${ }^{65}$ Alternatively, insurers may be seeking to minimize risk and reduce transaction costs in the most serious malpractice disputes.

A key parameter to measure would be the insurer's own assessment of liability, including a description of how that assessment was reached. In cases of clear liability where the plaintiff is willing to accept something close to actual economic damages, it would appear to be in an insurer's interest to settle early to avoid the cost of defense. The more interesting scenario is the case with questionable liability. Are insurers and plaintiffs in such cases able to reach a compromise without the formalities of the litigation process? Without the coercive powers of the discovery system, access to information needed to evaluate the case depends upon voluntary agreement. Do the

61. Eisenberg, Private Ordering Throngh Negotiation: Dispute Setllement and Rulemaking. 89 Harv. L. REV. 637 (1976).

62. Galanter, supin note 57, at 77-78 (citing H. Ross, Settifd Out of Court: The Social Process of Insurance Claims Adjustments (1970)).

63. Galanter, supra note 57, at 77 (citing Agent Orange case and Buffalo Creck disaster as evidencing substitution of payment of money for mutual assessment of responsibility, causation, relative blame, or other potentially more normative measures). See H. Gens, supra note 25.

64. Of the 22,814 claims settled without any formal adjudication, 7562 or $33.1 \%$ were settled without litigation being filed. GAO REPORT, supia note 16 , app. V at 82 (Table V.14).

65. The usually unspoken assumption is that the smaller, less significant cases are settled without litigation. Sep HEW REPORT, supra note 16, at 14 (Table 3 showing that all pre-litigation settements were for less than $\$ 20,000$ ). A compilation of data from four closed claims studies in the $1970^{\circ} \mathrm{s}$ revealed that approximately $90 \%$ of all compensation paid in malpractice cases was paid in litigated cases. This percentage exceeded an estimated $77 \%$ rate for payment in litigated cases in general liability cases and $33 \%$ in automobile cases. J. Kakat.1k \& N. PACE, supra note 10, at 31 (Table 3.3). 
insurers and plaintiffs in fact substitute informal discovery procedures or instead simply act upon imperfect information? Put differently, is the plaintiff (who typically has a greater need to access information) in a position to obtain the information necessary to assess the potential merits of the case?

Another potentially important variable is the experience level of the attorney representing the claimant. It may be that experienced lawyers have greater credibility with insurers and are thus more often able to settle a claim without resorting to litigation. Alternatively, it may be that inexperienced lawyers are more likely to settle at this earlier stage owing to an inability to present the claim well or ignorance of the appropriate "going rate" for a particular type of claim. One's view of the ultimate desirability of early settlements may well depend on which of these descriptions is more accurate.

Another critical qualitative factor is the manner in which expert evidence is used in settlements. In litigation, obtaining experts, discovering information about the other side's experts, and evaluating their opinions represent a critical and often contentious stage of the lawsuit. When this litigation reality is transposed to the pretrial process, it must play quite differently. Indeed, one should start by asking whether expert input is in fact even obtained in a significant proportion of claims. If it is obtained, a subsequent question concerns the degree to which the typically adversarial nature of the exchange is affected. Knowing more about how the parties either avoid this reliance on experts or else streamline it to suit the more informal negotiation process would be valuable. ${ }^{\text {it }}$

\section{Structuring the Settlement Process: The ADR Example}

Describing the process of settlement and assessing the qualitative nature of the settlement dynamic in the malpractice context would permit researchers to consider what procedural reforms might improve the settlement process. An analysis of obstacles to settlement that may exist in cases is important here. From existing research, we have little basis for assessing what constitutes the primary barriers to settlement-the defendant doctor seeking vindication, the recalcitrant plaintiff wanting a public humiliation of the doctor, the plaintiff's attorney looking for a larger fee, the insurer willing to run some risks to avoid paying money promptly, or the defense lawyer seeking to extend the hours to increase a fee? The identification of critical factors or procedural concerns in the settlement process may suggest many reforms. For example, we have seen a continued evolution of a judiciary actively involved in promoting settlements. ${ }^{67}$

66. Rescarching these issues in the pre-litigation area will not be easy, and will require the cooperation of the insurance industry since public records are usually non-existent. To take advantage of the opportunity fully, careful review of a significant number of individual files will be necessary since summary data will not permit analysis of many of the concerns raised above. Moreover, it would be preferable to include several different insurers in order to assess the variability of settlement practices among companies.

67. The literature on judicial involvement is extensive. Sep, e.g. Will, Merhige \& Rubin, The Role of the Jutge in the Setllement Process, 75 F.R.D. 203 (1977); W. Brazil., supra note 56. 
Improved information on the settlement process could provide activist judges with ideas as to how to structure discovery or focus negotiating issues. Similarly, any proposed further reform of the procedural system would benefit from this analysis. ${ }^{68}$

Perhaps the most significant potential use of improved empirical research on the settlement process would be in the development of alternative dispute resolution ("ADR") procedures for malpractice cases. Several groups or commentators have recently urged that ADR methods be used in malpractice cases at least on an experimental basis. ${ }^{69}$ While ADR is a somewhat amorphous concept, ${ }^{70}$ clearly one of its principal purposes is to improve the settlement process by either: (1) encouraging early and hopefully cheaper settlements; (2) settling presently unsettlable cases; or (3) improving the quality of the voluntary resolutions. ${ }^{71}$ In analyzing the performance of any ADR plan, the empirical issue can be defined in settlement terms: How useful is the alternative with respect to assisting the parties to evaluate cases as compared to the existing litigation process, and more particularly as compared to the method by which claims are currently being settled?

68. One suggested approach focuses upon a significant change in the dynamics of the settlement process. The proposal creates a strong incentive for doctors and hospitals to settle disputes early by providing that the potential malpractice defendant could offer to pay the injured patient's economic losses. In turn, the patient would give up any right to non-economic damages, that is, pain and suffering. See Moore \& O'Connell, Foreclosing Vedical Valpractice Claims by Prompt Tender of Economic Loss, 44 LA. L. REv. 1267 (1984). A bill providing for such a system was introduced during the $99 \mathrm{th}$ Congress (the Moore-Gephardt proposal). H.R. 3084, 99th Cong., 1st Sess. (1985). In some respects, this proposal is a radical variation of the efforts to provide for an "offer of settlement" within the established rules of civil procedure to provide the parties some clear incentives to settle.

69. U.S. General Accounting Ofrice, Medical Malpractice: a Framework for ACtion 30 31 (1987) (noting desirability of evaluating alternative dispute resolution mechanisms); SPFCIAL TASK force on Proffessional liability, AMa, Professional. Liability in the 80's: Report No. 3, at 6-7 (1985) (discussion of alternatives to litigation); id at 13-14 (recommendations relating to improvements in the liability resolution system including expanded use of pretrial screening panels and sanctions for filing frivolous litigation, and consideration of use of specific ADR forms such as court-ordered arbitration): Note, Health Care Providers and Allernative Dispute Resolution: Needed Medicine 1o Combat Medical Malpractice Claims, $4 \mathrm{~J}$. Disp. Resolution 65 (1988) (focusing on use of screening panels and arbitration). See M. Carbine, Health Care and the law: Devfioping, Flexible Dispute Resolution Mechanisms for the Health Care Fifld (1988); Nelson, Medical Malpractice and Alternative Dispute Resolution. 10 Am. J. Trial. ADvoc. 345 (1986). There have been regular and repeated calls among those in the medical profession to expand the use of arbitration. See, e.g., Powsner \& Hamermesh, Medical Malpractice Crisis the Second Time Around: II\%y . Not Arbitrale? 8 J. Legal MED. 238 (1987).

70. As commonly used in this litcrature, "alternatives to litigation" covers a disparate collection of concepts. Thus, the term is defined broadly enough to include the use of non-negligence-based compensation systems such as no-fault systems, the creation of "designated compensable events," or the formal restructuring of tort law requirements through private contractual arrangements. See HHS Rr.PORT, supra noic 6, at 136-44. See generally Havighurst, Prizate Reform of Torl Lau Dogma: .Markel Opportunities and Legal Obslacles, Law \& ConTemp. Probs., Spring 1986, at 143. As used in this article, I am limiting the phrase alternative dispute resolution mechanisms to its procedural manifestations, such as mediation, arbitration, or any of the various specific forms including courtannexed arbitration, mini-trials, summary jury trials, or the screening panel procedure.

71. Sep, P.g., Licberman \& Henry, Lessons from the Alternative Dispute Resolution IIovement, 53 U. CHI. I. RrV. 424, 427 (1986) ("ADR premised upon hypothesis that . . they could voluntarily reach a rottement as just as the result a court would impose"); Edwards. Alternative Dispute Resolution: Panacea "I Imulhrmu, 99) HaRv. L. REv. 668, 673 (1985) (noting the "cnormous settement-enhancing (m, indial of AI)R"). 
1. Assessing Existing ADR Programs as Settlement Devices: The Screening Panel Experience. To date, the use of alternative processes in malpractice cases has centered on two different techniques: arbitration ${ }^{72}$ and the screening panel procedure discussed above. The screening panel procedures, while primarily intended to deter frivolous litigation, are justified in part by the hope that the parties in meritorious cases will be able to use a panel's finding of liability and assessment of an appropriate compensation as a basis upon which to resolve the dispute without litigation. In order to benefit the settlement process, the parties and their attorneys must give significant weight to the panel's finding respecting liability, and, where authorized, the quantum of damages. In short, the settlement enhancing rationale can be cited only if the early intervention provides an evaluation that may establish a meaningful basis for settlement. ${ }^{73}$

Most research on screening panels is descriptive in that it focuses primarily on numbers of hearings held or disposition times. The research focuses indirectly on its impact on settlement due largely to the lack of a comparison data base on litigation against which to compare the panel's performance. ${ }^{74}$ Nonetheless, the limited empirical research that does exist raises significant questions about the potential utility of the procedure as an aid to the settlement process.

72. Arbitration is perhaps the most frequently mentioned ADR option for malpractice cases. Despite the attention that it has received, arbitration to date has been a minor factor in litigating malpractice cases. According to the reported results, the GAO found that less than 2000 claims out of its entire projected claim total of 56,000 were terminated either after arbitration or in anticipation of an arbitration proceeding. GAO REPORT, supm note 16, at 82 (Table V.14). While several modest empirical studies of arbitration have been conducted, none have attempted a comprehensive analysis of whether arbitration has affected the results in cases or what cost savings, if any, have been realized. For example, based upon a review of 36 arbitrated malpractice cases, a commillee empowered to review Michigan's arbitration program concluded that arbitration "was characterized by a shorter time from filing to disposition, lower expenses for defense of claims and more consistent awards." Memorandum from Rhonda M. Pow'sner to Saul Boyarskey, cited in Terry, The Technical and Conceptual Flaws of Medical Malpractice Arbitration. $30 \mathrm{Sr}$. Louis U. L.J. 571 , 573 n.11 (1986). This conclusion, apparently based upon a comparison with litigated cases going to trial, is open to serious question owing to possible differences in the character of cases involved.

Arbitration is intended primarily as a more efficient, cheaper, consistency-oriented means of reaching a binding decision; impacts on settlement are secondary. Sep Heinz. Arbitration of liedical Malpractice Claims: Is it Cost Effective?, $36 \mathrm{MD}$. L. REv. 533, 534-35, 548 (1977) (noting principal goals of arbitration to include speedy handling of cases, time savings for physicians, improved sophistication of decisionmaker, "more realistic awards," reduced discovery costs, and privacy of forum, but noting that arbitration as a practical matter results in settlement of cases). The primary impact on settlement would scem to come from the mere fact of scheduling an arbitration hearing in that it forces the attorneys to prepare and analyze their cases. Since such preparation can occur more quickly in an arbitration setting, earlier settlements may result. There would not appear to be any intended impact on the quality of settlements, except perhaps for a possible across-the-board reduction in dollar values of settlements given the lack of recourse to a jury. No empirical research to date has focused on the impact of arbitration on the settlement process.

73. The screening panel is typically justified in terms of both ferreting out non-meritorious litigation and assisting in prompt settlements of meritorious suits. See. e.g.. P. DaNzon, supra note 11 , at 198; Daughtrey \& Smith, supra note 48, at 275.

74. See P. DANzon, supra note 11, at 200. For typical examples of the descriptive research performed on screcning panels, spe Daughtrcy \& Smith, supra note 48. 
Recent data from Hawaii are illustrative. There, researchers tracked 453 screening panel decisions over a five-year period from 1979 to $1984 . .^{75}$ In 109 cases (or 24 percent of the total), the panel made a finding of liability. According to theory, these are the cases in which the parties should reach settlements earlier than in the past using the panel's determination as a basis of accord. According to the research. eighteen of these cases ( 16 percent of the universe of liability cases) in fact settled without the need for formal litigation. In almost half of the cases (fifty-three in total), the researchers report that the claimant took no further action, while in the balance (thirtyseven cases, constituting 34 percent) the claimants filed a lawsuit. ${ }^{76}$ Of the litigated cases, nineteen were settled (many for relatively small amounts), four went to trial (with the defendant somewhat surprisingly winning three of the cases), one was dismissed, and eight were pending as of the time the report was prepared.

The Hawaii study is particularly interesting because it is the only study that has information comparing the actual litigation result with the panel's suggested compensation level. ${ }^{77}$ While the number of cases in the sample is very small, the data are nonetheless revealing. The Hawaii study identified seventeen claims in which the panel found liability and made a determination of an appropriate compensation level, and the case subsequently settled for a known amount. The panel's liability awards in these cases ranged from $\$ 250$ to $\$ 750,000$. The ultimate dispositions varied significantly: Four claims settled for the same amount, and three for less, while ten settled for more than the panel's recommendation. No explanation is given as to the variances; the researchers concluded that the "final award of settlement figure varied widely from the recommended amount." 78

Perhaps even more interesting are the results from the cases in which the panel found no liability on the part of the doctor. In the sample group consisting of 453 hearings, "no liability" findings were made in 328 cases (72 percent). To be sure, the data suggest that for many of the cases, comprising approximately 70 percent of the "no liability" findings, the panel's decision ended the dispute. This phenomenon suggests that the panel is assisting in one primary function-the screening of non-meritorious claims. Yet, other data urge caution even in this respect, and specifically call into question the panel's function in aiding the settlement process. Despite the screening panel's findings, litigation was initiated in seventy-eight "no liability" cases (24 percent of the total). Dispositions were known for fifty-one of these cases. Significantly, despite the finding of no liability, thirty of these cases (or almost 60 . percent) were resolved with a payment to the plaintiff. While many

75. J. MaRdFin, supra note 20 , at 13.

76. Id. at 15 .

77. There are two reasons for the paucity of comparative data. First, since most panels were created in the mid- to late 1970 s, insufficient time has passed to collect such data. Second. only a minority of states using mandatory screening panels permit the panel to make a specific finding on damages. Spe P. Ebener, supra note 7, at 63-65 (Table IV.4).

78. J. MARdFin, supra note 20, at 26. 
involved small settlements, ten of the settlements in the "no liability" cases were for over $\$ 100,000$, and indeed, in three cases, payments of over $\$ 500,000$ were made to the plaintiff. These outcomes cannot be attributed to a biased jury; only one of the thirty cases resolved with a payment to the plaintiff after a "no liability" panel decision resulted from a jury verdict in favor of the plaintiff. 79

Given these results, how should we assess the screening panels' performance and, indirectly, the utility of this form of ADR for assisting the settlement process? To be sure, the Hawaii study is not complete, and some of its insights may be limited by small sample sizes. Nonetheless, it raises serious questions about the utility of the screening panels in improving the settlement process. In particular, one could question what happened in fiftythree of the 109 "liability" cases in which the researchers were unsure of the status of the claims; it is surprising that such a large number of claimants would simply abandon meritorious claims. If many of these claims have in fact settled (but the information was unknown), then one may reach a different conclusion about the utility of the screening process for settlement purposes.

One could argue that the data suggest that the screening process contributed positively to the settlement process. Of the cases in which the researchers knew the results, almost half settled without litigation, and the bulk of cases in which a lawsuit was filed settled short of trial. By the same token, however, more must be discovered about when they settled and the expense involved before one can draw confident conclusions. Moreover, four of the cases went to trial (constituting approximately 10 percent of the litigated "liability" cases), and this occurrence suggests a minimal impact on the part of screening panels, given that this percentage is approximately equal to the normal trial rate. ${ }^{.0}$ Even more troubling are the data suggesting a lack of correlation between the panel's damage assessment and the actual result. Not only do the researchers suggest that the panel's awards are regularly below the settlement rates in litigation, but the wide variance suggests overall unreliability. The concern is exacerbated by the surprising statistics from the "no liability" cases that are pursued through litigation: More than half of the plaintiffs received compensation-indeed sometimes significant compensation-despite the panel's "no liability" finding. In short, the data lead one to question the panel's ability to assess the value of the case. This

79. Id. Indeed, of the 11 "no liability" cases that went to trial resulting in a final judgment, defendants won 10 .

80. Id. This rate seems comparable to the usual trial rate in medical malpratice cases. See infra note 94. Danzon suggested that a likely possible impact of screening panels would be to increase the rate at which cases went to trial owing to a slight reduction in the incremental costs of litigating once the expenses associated with the screening panel have been incurred. P. DAN\%oN, supra note 11 , at 199-200. Other counterproductive impacts of the screening panel procedure have been positcd. See, e.g., Corodemus \& Ver Strate, Dark Viclory: The Doom of Medical Malpractice Panels, 5 Srton Hal.L LEGis. J. 31, 55 (1980) (suggesting the data relating to New Jersey's panel indicated that in cases where a finding of liability was made, it resulted in the plaintiffs significantly inflating their settlement demands). 
apparent inability may be a function of timing-it is simply too early to make a good assessment of damages or even liability at the panel stage. However, it may also reflect a more serious shortcoming in terms of the relevant expertise of panel members who may well have been selected for medical expertise as opposed to working knowledge of economics necessary to assess damages.

2. Potential Use of Other ADR Methods in Malpractice Cases. The lack of empirically proven success on the part of the screening panel, at least in terms of improving the settlement process, leads one to consider the utility of other alternatives. Newer ADR methods such as the summary jury trial, ${ }^{81}$ courtannexed arbitration, ${ }^{82}$ early neutral evaluation, ${ }^{83}$ and mini-trials ${ }^{84}$ have been employed on a limited scale in malpractice cases. To date, no empirical studies have been conducted evaluating the effectiveness of these particular ADR techniques in malpractice cases. As is generally true in the ADR field, there has been virtually no creative use of research projects to assist in the design of specifically tailored ADR programs for particular types of litigation. ${ }^{85}$

If such procedures should come to play a significant role in resolving malpractice cases, the same types of questions raised above in connection with the screening panel must be asked. A primary component of the theory of ADR is that it can provide useful information at appropriate stages in the evolution of the dispute to permit fair and less expensive settlements. Yet, in

81. See Lambros, The Summany Jury Trial, 103 F.R.D. 461 (1984). Given the relative infrequency of malpractice in federal court (owing to the usual lack of diversity jurisdiction), reports of summary jury trials in malpractice cases are few, although the process has been used. See Bockweg v. Clark, No. C-86-936-WS (M.D.N.C.) (summary jury trial held in Greensboro, N.C.. Apr. 1988). To date, only a few states have used or authorized the summary jury trial. Again, there are scattered accounts of using the procedure in malpractice cases, but the empirical work suggests that its use to date has been limited and its impact uncertain. Sep J. Alfini, L. Griffiths, R. Getchell \& D. Jordan, Summary Jury Trials in Florida: An Empirical Assessment 31 (1989) (of 43 summary jury trials studied in Florida state court, none were medical malpractice cases); Lockhart v. Patel, 115 F.R.D. 44 (E.D. Ky. 1987).

82. Sep, e.g. Hensler, What II'e Know and Don't Know About Court-.tdministered Arbitration, 69 Judicature 270 (1986). In most state court programs, the dollar value of cases assigned to courtannexed arbitration programs is limited, with $\$ 15,000$ to $\$ 25,000$ being the norm. Given these relatively low ceilings, few. if any, malpractice cases would be expected to go through the process. While the federal courts have higher dollar limits (usually $\$ 100,000$ ), fewer malpractice cases are filed in the federal courts owing to jurisdiction limitations. Nonctheless, some malpractice cases have gone through the process. See, e.g., Frazier v. Urgent Medical Care Center, No. C-87-231-G (courtannexed arbitration hearing. M.D.N.C. Apr. 27, 1988).

83. See Brazil, Kahn, Newman \& Gold, Early Veutral Evaluation: An Experimental Effort to Expedite Dispule Resolution, 69 Jubicature 279 (1986); Levine, Northem District of Califormia Adopts Early . Veutral Evaluation to Expedite Dispute Resolution, 72 Judicature 235 (1989).

84. See, e.g. Olson, In . Altermative for Large Case Dispute Resolution. Litication, Winter 1980, at 22; Center for Public Resources, Containing legal Costs: ADR Stratrgits for Corporations, I AW Firms, and Government $33-43$ (1988).

85. Literature on designing resolution for specific dispute contexts is relatively recent, and none focuses specifically on medical malpractice. See W. UrY, J. Bretr \& S. Goldberc. Gettinc. Disputes Resolved (1988) (general discussion of factors to include in designing dispute systems followed by case study of coal industry); Center fOr Public Resources, supra note 84 (describing ADR stratcgies in a varicty of commercial contexts including products liability disputes, toxic tort cases. hazardous waste disputes, employment disputes, and technological disputes). 
many cases, there are reasons to question whether in fact ADR can deliver on its promise. For example, the summary jury trial is an ADR procedure that occurs in theory after most or all discovery has been completed. The procedure itself requires significant preparation time. Even if the procedure is successful in the sense that a settlement is reached after the summary jury trial, the empirical question remains whether any significant cost savings were in fact realized.

Another trend in the ADR field presents other questions. Recently, considerable energy and interest have been given to the potential use of mediation techniques in resolving an increasing variety of disputes. The process of mediation involves the efforts of a neutral mediator, who assists the parties in identifying areas of agreement, in the hopes that the parties themselves can negotiate a compromise solution. ${ }^{87}$ At times, the mediator can play a more active role in suggesting possible areas of compromise. In theory, mediation is perceived as a useful dispute resolution technique where there is a need for the disputants to maintain a working relationship, such as with divorcing parents negotiating a child custody arrangement. To be sure, the term mediation is not always used consistently; some states' screening panels seem to suggest that they play a mediation role. ${ }^{x 8}$

Despite the fact that malpractice has not been identified as an area particularly well suited to the process, mediation has been used increasingly as an alternative to the litigation process. For example, judges in a handful of states now have the power to require the parties to mediate their dispute. ${ }^{89}$ In fact, malpractice cases have been regularly referred to mediation under Florida's new program. Wisconsin is also experimenting with a pretrial procedure that has at least elements of a mediation plan. ${ }^{90}$

86. Cf. Posner, The Summary Jury Trial and Other Wethods of Alternative Dispute Resolution: Some Cautionary Observations, 53 U. Cir. L. REv. 366 (1986) (discussing lack of empirical evaluation of summary jury trial).

87. Sep generally S. Goldberc, E. Green \& F. Sander, Dispute Resolution 91 - 147 (1985). The Florida ADR Act of 1987 defines mediation as "a process whereby a neutral third party acts to encourage and facilitate the resolution of a dispute without prescribing what it should be. It is an informal and nonadversarial process with the objective of helping the disputing partics reach a mutually acceptable agreement." FLA. STAT. ANN. \$44.301 (West 1988).

88. For example, the title of the reviewing body in Hawaii is the Medical Claim Conciliation Panel. Sef J. Mardfin, supra note 20. at $\mathrm{i}$. Despite the fact that the process is sometimes referred to as "mediation," the panel is not given any explicit directions to attempt to assist the parties in reaching a voluntary agreement. See id. at 6-8. Rather, it is hoped that their decision will guide the parties lowards a resolution.

89. See Fla. Stat. ANN. $\$ \$ 44.301-.306$ (West 1988) (ADR Act of 1987) (authorizing court in any civil dispute to refer case to mediation or non-binding arbitration); Tex. Civ. Prac. \& REm. CoDE $\S \S 154.001-.073$ (West Supp. 1987) (Alternative Methods of Dispute Resolution Act of 1987) (same).

90. Mediation may be requested prior to commencing suit, but must be requested within 15 days after the suit was filed. Wis. STAT. AnN. $\$ 655.445(1)$ (West $1980 \&$ Supp. 1988). The mediation will take place within 90 days before a three-member panel consisting of an attorney, a doctor, and a public representative. Id. $\$ 655.465$. Pending the expiration of the mediation period, no discovery may be conducted. Id. $\$ 655.58(2)$. Parties are expected to attend the mediation, and their attorneys must be prepared to discuss in good faith both liability and damage issues. In fact, the mediation panel is expected to make a finding on liability and a suggested damage award, thus calling into serious question whether the proceeding is in fact a mediation or simply a variation upon the existing screening panel's typical non-binding arbitration approach. Spe R. SProule. SUPrEmF. 
Despite the recent advent of mediation in the malpractice area, there has been no systematic study of mediation programs in malpractice cases. Summary statistics from the $W$ isconsin program raise some initial concerns. Of the first 250 cases that were processed through the mediation panels, only twenty-two cases, representing 9 percent of the total, settled as a result of the mediation. This total, substantially below the initial settlement rate achieved by most screening panels, may suggest either that the particular procedure used requires refinement, or that mediation may not be a useful process-at least as a requirement in all cases or at such an early point in the case."1

The use of ADR procedures in malpractice cases thus requires exploration of essentially uncharted waters. Empirical research, which has not yet played a creative role in analyzing the dynamics of the settlement process, could play an important role in the ADR design process. First, empirical research could bear on the question whether a particular category of disputes-such as medical malpractice claims-is sufficiently uniform to suggest a single alternative process. For example, the recent American Medical Association suggestion of an alternative system for resolving malpractice claims consists of a single approach to be substituted for the present system." This suggestion necessarily assumes that most malpractice cases are sufficiently alike to benefit from this uniform, albeit alternative, process. In fact, research might show that malpractice cases-defined in terms of such variables as: (1) amount in controversy; (2) factual complexity; (3) variety of factual and legal issues presented; and (4) damages-fall into significantly distinct categories so that a flexible ADR approach, such as the "multi-door courthouse approach" now being experimented with in several courts, is preferable. 93

Second, even in designing a single alternative process, empirical research, if done in such a way as to reveal something of the settlement process itself,

Court of Wisconsin Medical Mediation Panfis: Guidelines for Mrdiation (1988) (available from Administrator. Medical Mediation Panels, $110 \mathrm{E}$. Main St., Suite 320, Madison, Wis. 53703).

91. The Wisconsin Litigation Project is currently carrying out a research project into the Wisconsin Mediation program pursuant to a grant from the State Justice Instilute. Sep C. Meschicvitz, Mediating Medical Malpractice Cases in Wisconsin: A Preliminary Report (paper presented at Law and Society Association Meeting in Madison, Wis., June 1989). Farly statistical information raises questions about the utility of the procedure. As of February I, 1988, only 22 out of the initial 250 cases $(9 \%)$ had setted during or shortly after the mediation process. R. Sproule, Status Report of Medical Mediation Panels (Feb. 1, 1988) (available from R. Sproule. Administrator. 110 E. Main Street, Suite 210, Madison, Wis., 53703). A full 69\% of the claims had ripened into court disputes, although in approximately half of these cases the attorneys opined that mediation had served a "constructive purpose." Id.

92. AMA, supra note 5. The plan combines a number of different resolution strategies. After an initial investigation phase conducted by an emplovee of the agency charged with administering the resolution of the disputes, the claim is subject to an evaluation by a neutral cxpert witness. Assuming the claim is still considered to have merit, a hearing officer is assigned. Prior to the hearing, blind settlement offers are exchanged to see if the parties agree. If not, the officer is authorized to attempt to mediate the dispute prior to the arbitration of the case. For a description and analysis of the AMA proposal, compare The Future of Health Care in America: Hearings Before the Subcomm. on Education and Health of the Joint Economic Comm., Part 2, 100th Cong., 2nd Sess. 445 (1988) (statement of Carter G. Phillips), with id. at 516 (statement of Thomas B. Metzloff).

93. See, e.g. Edelman, Institutionalizing Dispute Resolution Allermatizes, 9 Just. Srs. J. 134, 140 $(1984)$. 
could provide important insights regarding specific procedural features to be included. For example, if the research revealed that settlements are impeded primarily through the recalcitrance of the defendant doctors themselves (as opposed to the attorneys), it may be necessary to include the doctor in whatever process is suggested. Many ADR techniques, including mediation and the mini-trial, seek to involve the client more directly in the process.

Research into the discovery process and its relationship to settlement, as already noted, should also reveal important insights. If early settlement is a goal, understanding what discovery in fact usually precedes settlement may prove vital. For example, if a sizable number of settlements occur after the deposition of the defendant, then perhaps a preferred procedural template for malpractice cases should require or at least suggest that this deposition occur early in the process. In addition, patterns of pre-litigation settlement would certainly suggest potentially attractive avenues for developing ADR mechanisms. Another major challenge here would be an improved understanding of the use of expert opinion by the parties in the settlement process. Malpractice cases are distinctive in that they routinely require expert analysis. To date, ADR theory has not focused clearly on the challenge of employing experts.

\section{IV}

The Role and Performance of the Jury in Malpractice Litigation

As with other types of litigation, only a small fraction of medical malpractice cases-fewer than 10 percent-are resolved by a jury."4 Nevertheless, the influence of jury verdicts is seen as central in explaining the medical malpractice crisis. Jury verdicts arguably provide the going rate for specific types of injuries, thus establishing the framework for negotiation and settlement of similar malpractice claims. 95 Further, some argue that increases in the number and size of awards increase the rate at which claims are asserted

94. P. DAnzon, supra note 11 , at 31-32 (noting that about $7 \%$ of a sample of 6000 claims closed in 1974 and 1976 were tried to a verdict); GAO REPORT, supra note 16, at 37 (indicating that of claims closed in 1984 only about 5\% were tried to completion). Preliminary results from our study of litigated malpractice cases (where a lawsuit is filed) in North Carolina between 1984 and 1987 indicate that about $7 \%$ of malpractice suits actually went to jury trial.

95. See, e.g. S. Daniels \& L. Andrews, The Shadow of the Law: Jury Decisions in Obstetrics and Gynecology Cases 3-4, 9 (1988); H. Kalven and H. Zeisel., The American Jury (1966); H. Ross, Setrled Out of Court: The Social Process of Insurance Claims Adjustment (1970); Alschuler, Mediation with a Mugger: The Shortage of Adjudicative Services and the Veed for a Two Tier Trial System in Civil Cases, 99 Harv. L. REv. 1808 (1986); Mnookin \& Kornhauser, Bargaining in the Shadow of the Law: The Case of Dizorce, 88 Yal.E L.J. 950 (1970). Cf. Willard, The Medical Malpractice Crisis, in Mrdicai. Malpractice-Tort ReForm 6 (1987) (describing $\$ 65$ million malpractice judgment, which, even after being reduced to $\$ 3.3$ million by the court, "influences plaintiffs and their attorneys to press marginal or frivolous claims, and it often forces insurers into settling cases for far more than they are realistically worth"). 
by raising the expected payoff from litigation. ${ }^{96}$ In short, what juries do, or are perceived as doing, colors the entire litigation process.

Perhaps it is not surprising, therefore, that the frontal assault by critics of the malpractice litigation system is often directed at the jury. Many go so far as to conclude that the present system is nothing short of a lottery; others label jury verdicts as "capricious," claiming that juries fail to compensate some plaintiffs adequately and vastly overcompensate others. ${ }^{97}$ Underlying these assertions is a premise about competence: Groups of laymen cannot understand or effectively evaluate the complex issues of causation and the appropriate standard of medical care presented in most malpractice cases. ${ }^{98}$

Given both the public nature of the jury's involvement and its perceived importance, empirical analysis of the jury's role would be important in assessing the accuracy of the criticisms. As proof of the jury's inabilities, the critics assert that there has been a dramatic and unjustified increase in malpractice jury awards over time, which is a manifestation of a perceived pro-

96. See Danzon, The Frequency and Severity of Medical Malpractice Claims: New Evidence, LAw \& Contemp. Probs., Spring 1986, at 57.

97. AMA, supra note 5, at 4 (statement of Jeffrey O'Connell that results of jury system "are often fortuitous, yet society pays high costs for operating this unsatisfactory lottery"). See PRIVATE SECTOR Conference, supra note 10, at 81 (statement of James $S$. Todd that "[w]e apparently have a system that is slow, expensive, cumbersome, inequitable, and probably patently unfair"); Daniels and Andrews, supra note 95, at 2-3; Nutter, The Fight for Civil Justice Reform, Ins. Rev., Nov.-1)ec. 1984, at 2; Weaver, The . Model Health Care Provider Liability Reform Act, 49 N.C. Med. J. 621, 623 (1988) ("[t]he current jury system is expensive, unpredictable, time consuming, and as a result, inequitable for all parties").

98. Private Sector Conference, supra note 10, at 17 (statement of John A.D. Cooper noting that the "complexity of modern medical care makes it increasingly difficult for a jury" to distinguish between physician negligence and the inherent risks of interventionist techniques); Schwarz, liability Crisis: The Physician s l'ieupont, in Medical. Malpractice-TorT Rerorm 24 (1987) (Juries are "seemingly incapable of separating their personal feelings from the evidence in the cases and instinctively wish to help the plaintiffs as they would want others to help them if they were in a similar situation.").

At another level, the medical profession is simply uncomfortable with permitting lay people to serve as judges of professional standards. A good example of this point can be found in a recent paper based upon a panel discussion published by the Roscoe Pound Foundation. After a lengthy discussion in which there was substantial agreement that juries frequently find for the defendant, a medical representative, while agreeing with the results, refuted the consequences noting that doctors "have an inherent hatred and distrust of the system... and they are going to do anvthing and everything within their economic power to take it to another forum . . even though the statistics don't bear out the idea that there are going to be any more defense verdicts, or any lower ones ... doctors can't stand having lay people try their cases even though they do wonderfully lbefore them|." J. Guinther, supra note 11 , at 11 .

In addition to the competency critique, commentators have alleged that jury trials are overly time consuming and expensive. A recent study based upon direct observation of 58 professional malpractice trials in three different states-a small sample to be sure-indicated an average malpractice trial length of approximately 17 hours, compared to an average civil trial length of slightly over 13 hours. D. Sipes \& M. Oram, On Trial: The. Length of Civil. and Criminal Trial.s 9-10 (1988). This average exceeded, although only slightly, the average trial lengths for motor vehicle cases, contract disputes, other tort cases, and "other civil" cases, but was notably less than the 26 hour, 23 minute average for product liability cases. Id. To be sure, there are likely to be significant variations among courts depending upon local practice, judicial management, and the complexity of the malpractice cases being tried. Id. at 27 (noting high of 41 hours, 5 minutes in Denver compared to low of 12 hours, 57 minutes for a single (rial in Marin County, Cal.) Based upon our preliminary review of jury trials in North Carolina, the average time for a medical malpractice trial is approximately five days, although significant variations do exist. 
plaintiff bias. While the alleged problem of runaway juries transcends medical malpractice, the problem is thought to be especially severe in this litigation context.9' Given the jury's discretionary power to award damages, especially non-economic and punitive damages, the result is said to be a system out of control. ${ }^{100}$

\section{A. Studies of Jury Decisions}

Unlike criticism regarding other litigation issues on which little or no empirical evidence exists, some of the criticisms of juries have been buttressed with references to empirical studies. In some instances, however, the studies are methodologically inadequate. ${ }^{101}$ In other instances, the critics have ignored the limited application of the few actual studies addressed to the question of what juries do in malpractice trials. ${ }^{102}$ These studies, which are summarized below, provide some information about jury behavior, but are equally instructive in what they do not tell us.

Danzon and Lillard conducted the first systematic study of jury outcomes in medical malpractice cases. ${ }^{103}$ Their data set was derived from insurance company files involving approximately 6000 claims that were closed in 1974 and 1976. The files lacked much potentially important data, ${ }^{10+}$ but they were

99. M. Peterson, Compensation of Injuries: Civil Jury Verdicts in Cook County 35 (1984).

100. Another aspect of the jury critique is the concern with punitive damages. To date, there is no empirical evidence 10 establish that juries in malpractice cases award punitive damages on anything approaching a regular basis. Instead, the existing studies, dealing with a wider variety of malpractice cases, tend to show that punitive damages: (a) are infrequently awarded by juries; (b) tend to be confined mostly to cases involving intentional torts; and (c) are usually modest in size when they are awarded. There were only a few cases involving malpractice awards reported in these studies. Sep M. Peterson, S. Sarma \& M. Shanley, Punitive Damages: Empirical. Findings (1987): M. Peterson, S. Sarma \& M. Shanley, Punitive Damages: A Relic That has Outhived its Origins (1987). See generally S. Daniels \& J. Martin, Empirical Patterns in Punitive Damage Cases: A Description of Incidence Rates and Awards (paper presented at Law and Society Association Meeting in Washington, D.C., June, 1987).

101. Sep Localio, Jariations on S962,258: The Misuse of Data on Medical Malpractice, 13 LAW MED. \& Health Care 126 (1985), and J. Guinther, The Jury in America 192-93 (1988). Localio reports that a 1982 report based on data gathered by Jury Verdicts Research, Inc., was quoted in congressional hearings to support arguments that jury verdicts are out of control. Those data indicated that the average malpractice award was $\$ 962,258$, but there are multiple grounds for treating this figure as extremely misleading. First, the total sample consisted of 238 cases. Second, the cases were derived from newspaper clippings and reports voluntarily submitted by attorneys; this form of selective data gathering will result in reporting of large awards but not modest awards or defendant victories. Third, even with this unrepresentative sample, the average award can be a highly misleading summary statistic since it can be inflated dramatically as a result of a few very large awards. The more useful statistic is the median, which is the midpoini of the distribution of awards. J. Guinther, supra, at 193, reports that the median award for the Jury Verdict Research, Inc., distributions was approximately $\$ 200,000$, a figure that is much less starting. The methodological criticisms of verdict reporter research with respect to all categories of cases have been made previously. See N. Vidmar, On Libel and Civil Juries (paper presented at Law and Society Association Mecting in Washington, D.C., June, 1987).

102. See Nutuer, supra note 97; Saks, In Search of the "Lausuit Crisis," 14 Law Mrd. \& Heatru Carf 77 (1985).

103. Danzon and Lillard, Selllement Out of Court: The Disposition of Medical Malpractice Claims. 12 J. Legal Stud. 345 (1983). See also P. Danzon, supra note 11, at 31-57.

104. See P. DAnzon, supra note 11, at 31. For each claim, the files include information about the plaintiff, the defendant, the severity of the injury, the insurer's estimate of economic loss, the date of 
sufficient to allow the researchers to report some summary statistics and to utilize regression analyses to test hypotheses about relationships between different variables associated with case outcomes. The researchers made the following basic findings: In the 7 percent of the sample cases resolved by jury, plaintiffs prevailed only about one time in four. ${ }^{105}$ When the plaintiff did prevail, the average award was $\$ 102,000$. This figure was substantially higher than the average recovery of $\$ 26,000$ in those cases that were settled. ${ }^{106}$

Significantly, Danzon and Lillard's model noted the importance of identifying the characteristics of those malpractice cases that actually went to trial as opposed to those that were dismissed or settled prior to trial. Given that only a small proportion of litigated cases are tried, the question whether that proportion reflects a particular selection bias is critical in understanding the role and performance of the jury. Significantly, Danzon and Lillard concluded that cases that went to trial were not typical malpractice cases. Instead, they found that trial cases consisted primarily of cases in which: (1) liability was difficult to prove; (2) large potential damages were involved; and (3) the plaintiff's proof was relatively weak. Thus, the cases that actually went to trial were

"self selected" to that stage of disposition precisely because the outcome was unpredictable to the litigants, the potential award was large, and the evidence for the plaintiff was weak. Thus we get a very biased impression of the operation of the malpractice system from observing the minority of more visible cases that are litigated to verdict rather than the great majority of cases that are settled out of court. ${ }^{107}$

the injury, the dates of the filing and closing of the claim, and the outcome-amount of payment and state of disposition. Only the 1974 survey reports specific allegations made by the plaintiff, and only the 1976 survey reports whether the plaintiff had attorney representation. The insurance company claim files give no information about the bargaining process that led up to the outcome, nor do they indicate what the outcome of a settled case might have been if it had been taken to verdict.

105. Id.

106. Id. at 31; Danzon and Lillard, supra note 103, at 347.

The Danzon and Lillard data also provide some insight into the types of cases in which plaintiffs won. The probability of the plaintiff prevailing at trial was lower if the claim was based on allegations of misdiagnosis or failure to obtain informed consent than if it involved obvious error or if the doctrine of res ipsa loquitur was invoked. P. Danzon, supra note 11 , at 38-39. The plaintiff's probability of obtaining a favorable verdict was also greater if the injury was permanent rather than temporary, and greater still if the injury was fatal. Id. at 38. See J. Guinther, supra nole 101, at 179 (noting that large verdicts were clearly associated with grave or major injuries, thus providing little credence to the "jackpot" criticism of juries in malpractice cases). Although the data on economic loss were incomplete, Danzon utilized three rough measures of compensable injury-the insurer's estimate of economic loss, the severity of injury, and the age of the plaintiff-to analyze the question and determined that there was evidence that the degree of economic loss was positively related to the amount of damages awarded. P. DANZON, supra note 11, at 40. Specifically, she found that the median shadow verdict for claims involving permanent disability was roughly twice that for claims involving death. $I d$. However, the data tended to indicate that juries did not give higher awards to plaintiffs with higher earning power, a result that is inconsistent with the legal goal of compensating according to economic loss. Id.

107. P. DANZON, supra note 11 , at 51. A number of econometric models relating to the bargaining process have attempted to analyze the selection bias in order to predict which subset of cases is more likely to go to trial. Most such studies have similarly indicated that cases with potentially large awards are likely to be tried. See Wituman, Dispute Resolution. Bargaining, and the Selection of Cases for Trial: A Study of the Generation of Biased and l'nbiased Data, 17 J. Legat. Stud. 313 (1988); Priest \& Klein. The Selection of Disputes for Litigation. $13 \mathrm{~J}$. Lecal. STud. 1 (1984). While these discussions relate to litigation generally, related works focus on malpractice. Danzon \& Lillard, supra note 103. 
TABLE 1
Malpractice Verdicts in Cook Co., Ill., and San Francisco Co., California

\begin{tabular}{|c|c|c|c|c|c|}
\hline $\begin{array}{c}\text { Jurisdiction/ } \\
\text { Period }\end{array}$ & $\begin{array}{l}\text { Number } \\
\text { of Trials }\end{array}$ & $\begin{array}{l}\text { Percent of } \\
\text { All Trials }\end{array}$ & $\begin{array}{c}\text { Proportion of } \\
\text { Plaintiff Victories }\end{array}$ & $\begin{array}{c}\text { Median Award } \\
\text { in } \$ 000^{* *}\end{array}$ & $\begin{array}{l}\text { Average Aw: } \\
\text { in } \$ 000^{* *}\end{array}$ \\
\hline \multicolumn{6}{|l|}{ Cook County } \\
\hline $1960-64$ & 56 & $2 \%$ & .25 & $\$ 35$ & \\
\hline $1965-69$ & 68 & $2 \%$ & .29 & $\$ 48$ & $\$ 83$ \\
\hline $1970-74$ & 100 & $3 \%$ & .29 & $\$ 127$ & $\$ 605$ \\
\hline $1975-79$ & 134 & $5 \%$ & .33 & $\$ 141$ & $\$ 324$ \\
\hline $1980-84$ & 162 & $5 \%$ & .49 & $\$ 121$ & $\$ 1179$ \\
\hline $\begin{array}{l}\text { Jurisdiction/ } \\
\text { Period } \\
\end{array}$ & $\begin{array}{l}\text { Number } \\
\text { of Trials }\end{array}$ & $\begin{array}{l}\text { Percent of } \\
\text { All Trials }\end{array}$ & $\begin{array}{c}\text { Proportion of } \\
\text { Plaintiff Victories } \\
\end{array}$ & $\begin{array}{l}\text { Median Award } \\
\text { in } \$ 000^{* *}\end{array}$ & $\begin{array}{l}\text { Average Aw: } \\
\text { in } \$ 000^{* *}\end{array}$ \\
\hline \multicolumn{6}{|l|}{$\begin{array}{l}\text { San Francisco } \\
\text { County }\end{array}$} \\
\hline $1960-64$ & 95 & $7 \%$ & .27 & $\$ 64$ & $\$ 125$ \\
\hline $1965-69$ & 88 & $6 \%$ & .35 & $\$ 157$ & $\$ 306$ \\
\hline $1970-74$ & 98 & $7 \%$ & .43 & $\$ 124$ & $\$ 409$ \\
\hline $1975-79$ & 81 & $8 \%$ & .32 & $\$ 99$ & $\$ 644$ \\
\hline $1980-84$ & 55 & $9 \%$ & .53 & $\$ 156$ & $\$ 1162$ \\
\hline
\end{tabular}

* * Adjusted for general rate of inflation, awards are in 1984 dollars.

Source: M. Peterson, Civil Juries in the 1980's: Trends in Jury Trials and Verdicts in California and Cook County, Illinois (1987).

A series of studies undertaken by researchers at Rand's Institute for Civil Justice also provides information about jury outcomes in malpractice cases. ${ }^{108}$ The data were derived from verdict reporters ${ }^{109}$ for Cook County, Illinois, and a number of California courts including some in San Francisco. The time period was extensive, covering twenty-five years between 1960 and 1984, and thus allowed for analyses of trends over time. The research focus was inclusive of all types of cases, but disaggregations of types of claims, including malpractice, were made. ${ }^{110}$

108. M. Peterson \& G. Priest, Trends in Trials and Verdicts, Cook County, Ilinois, 19601979 (1982); M. Peterson, Compensation of Injuries: Civil. Jury Verdicts in Cook County (1984); A. Chin \& M. Peterson, Dekp Pockets, Empty Pockets: Who Wins in Cook County Jury Trials (1985); M. Peterson, Civil. Juries in the 1980s: Trends in Jury Trials and Verdicts in California and Cook County, Illinois (1987) |hereinafter Civiı. JuRies|.

109. "Verdict reporters" is a generic name for compilations of jury verdicts. Typically, they report the type of case, the names of plaintiff and defendant, the names of legal counsel, the names of expert witnesses, and the verdict. Verdict reporters vary in their degree of comprehensiveness, with some reporting only selected cases within a given jurisdiclion, see supra note 101 , and others reporting all cases; the amount of additional information provided also varies. For an overview and discussion of verdict reporters as sources of data, see $S$. Daniels, Civil Juries: Jury Verdict Reporters, and the Going Rate (paper presented at Law and Socicty Association Meeting in Chicago, Ill., May $1986)$.

110. The Rand studies have not disaggregated medical malpractice cases from other forms of malpractice such as legal or accounting malpractice. However, these latter types of cases account for a small fraction of the cotal of malpractice cases and are unlikely to affect significantly any conclusions drawn about medical malpractice. Letter from 1). Hensler. The Institute for Civil Justice, to N. Vidmar (1988). 
Some of these data, derived from various tables in a recent report, "' have been collated in Table 1. The table shows that in both Cook and San Francisco Counties the chance of a plaintiff victory (if one focuses solely on jury trials) almost doubled between 1960 and 1984, from one chance in four to one in two. The table also shows that the average award increased dramatically in both jurisdictions over the quarter century, but the rise in the median award, while substantial, was not nearly so great. This research suggests that a relatively small number of very large awards were given; typical awards were more modest. The final two columns show, however, that the two counties exhibited very different trends in the number of malpractice trials and the percentage of the trial docket taken by malpractice cases. In Cook County, the number of malpractice trials increased almost 300 percent from 1960 to 1984 (from 56 to 162), but in San Francisco the number of trials decreased by almost 50 percent (from 95 to 55 ). At the same time malpractice cases consumed a greater percentage of the trial calendar in both counties.

Although the lack of additional information prevents development of causal hypotheses, one can draw at least one important conclusion: Despite similarities in trends of plaintiff victories and damage awards, the two jurisdictions must have had significantly different settlement patterns resulting in different types of cases being tried. In other words, the profile of the subset of malpractice cases actually going to trial over time must surely have changed significantly and in different ways in these two jurisdictions. The interesting question then involves understanding the reasons for the change, which would seem to involve different settlement patterns having developed among insurers, defense attorneys, and plaintiffs' attorneys. Unfortunately, the verdict reporters do not inform us further on this question. All that is known is that the data strongly support the inference that between jurisdictions and within jurisdictions over time, juries were probably trying different types of malpractice cases. This makes comparative conclusions of any sort difficult without extensive additional data to provide statistical control over the differences, whatever they may be.

Stephen Daniels and his colleagues at the American Bar Foundation ("ABF") have also gathered data on malpractice cases by utilizing verdict reporters." 12 One important aspect of this research is its breadth of coverage: forty-six counties in eleven different states between 1981 and 1985.113 An important finding from the data set is the significant variations that exist among jurisdictions on a number of variables. Indeed, probably the most important conclusion to be drawn from Daniels' research is that there appear to be no discernible nationwide trends in malpractice verdicts and awards.

111. M. Peterson, Civil. Juries, supra note 108.

112. S. Daniels \& L. Anderews, supra note 95. Sep Daniels and Martin, Jury l'erdicts and the "Crisis" in Civil Justice, 11 Just. Sys. J. 321 (1986).

113. S. Daniels \& L. Anirfws, supra note 95, at 9 (Table 1). These locations were not a representative sample in the statistical sense, but they do reflect data collected from an array of diverse jurisdictions ranging from large urban counties, including major cities such as Los Angeles, Chicago, and New York, to several smaller metropolitan areas. 
First, there are significant differences as to how much of the trial docket is made up of malpractice cases. Thus, in the eleven New York counties included in the sample, over 17 percent of all civil cases that went to trial were malpractice cases as compared to only 3.9 percent in the two Texas counties included. ${ }^{14}$ Second, there was a wide variation in plaintiff's success rates in malpractice cases both within and among states: Among the seven Illinois counties, success rates varied from about 18 percent to 47 percent; in New York, the variation ranged between 20 percent and 56 percent. ${ }^{115}$ In all but two small counties, however, one pattern emerged: The plaintiff's success rate in malpractice cases was below the overall rate of success across the entire range of verdicts. ${ }^{116}$

The ABF work is especially interesting given that it involves a sufficient number of observed cases to provide a further breakdown on an important subcategory of malpractice cases: obstetrical and gynecological ("OB-GYN") cases. Their sample included 364 verdicts in OB-GYN cases, in which plaintiffs prevailed in 134 , a success rate approximately the same as that in the universe of malpractice cases, although again, substantial variations among

114. Id. at Iable 3. An interesting question is whether this wide variation could be explained at least in part by different jurisdictional provisions affecting the character of cases litigated in the particular courts studied. To the extent that a state employs specialized courts to handle particular types of cases, the docket of the court handling malpractice cases, usually the court of general jurisdiction within the state, could be significantly affected. The report does not describe any jurisdictional differences among the courts studied.

115. Id.

116. In 44 out of 46 counties, the plaintiffs' success rate in malpractice cases was below the overall success rate. The only exceptions were Clay County, Mo., and Spokane, Wash., each of which had a total of only four malpractice verdicts. Interestingly, the variation among plaintiffs' success rates was fairly consistent in the largest counties. Thus, for the six counties with over 1000 total verdicts, the variations were as follow's: (1) Maricopa County, Ariz., 58.4\% overall success rate as compared to $28.0 \%$ success rate in malpractice cases; (2) Los Angeles County, Cal., 55.7\% to 30.8\%; (3) Cook County, Ill., 57.9\% to 33.8\%; (4) New York County, N.Y., 64.6\% to 43.3\%: (5) Dallas County, Tex., 50.9\% to $21.4 \%$; and (6) Harris County, Tex., 55.5\% 10 10.3\%. Id. at 13 (Table 3 ).

This polycentric picture can be supplemented by descriptive accounts provided by individual state reporting agencies. For example, a limited study of jury verdicts in Dade County, Fla.. between January 1985 and March 1987 indicates that plaintiffs prevailed in $53.9 \%$ of malpractice cases that went to trial. The median damage award was between $\$ 50,000$ and $\$ 250.000$, but the mean. or average, award was $\$ 885,767$. The discrepancy between mean and median can be ascribed to the fact that 12 of the 62 awards (19.4\%) excecded onc million dollars. Punitive damages were awarded in only $4.8 \%$ of cases (or three cases in total) where the plaintiff received compensatory damages. In contrast, punitive damages were awarded in $6.7 \%$ of all types of jury verdicts. SPe FI.ORIDA ACADEMIC Task Force for Rrview of the Insurance and Tort Sistrms, Final Fact-Finding Report on Insurance. And Tokt Systrms 248-257 (Mar. 1, 1988). See generally Gifford \& Nive, Litigation Trends in Florida: Saga of a Growth State, 39 U. FLA. L. RFV. 829 (1987).

In Kansas, data on 1988 trials indicate that 23 malpractice cases went to trial. Plaintiffs prevailed in seven cases $(30.4 \%)$. The median award was $\$ 125,000$, but two of the malpractice verdicts were for over one million dollars. Across the range of civil litigation cases, only six verdicts (including the Iwo malpractice cases) exceeded one million dollars. No punitive damages were awarded in any malpracice case. Orfick of Judicial Administration, Kansas Judicial Center, Jury Verdicts in loRT CASES (1)eC. 1988). 
courts were noted. ${ }^{117}$ Indeed, the researchers provided even a further breakdown among types of OB-GYN cases defined in terms of established injury characteristics. ${ }^{118}$

The most interesting findings here related to those OB-GYN cases involving the management of labor and delivery. These claims are generally understood to be among the most significant malpractice claims and indeed have served as areas of special legislative attention; ${ }^{19}$ accordingly, any findings relating to them are especially noteworthy. With respect to this important group of cases, the plaintiffs' success rate was 44.7 percent, which was above the overall OB-GYN rate of 36.8 percent and above the overall malpractice rate of 32.4 percent. ${ }^{120}$ Moreover, the median level of damages for this group was the highest recorded. ${ }^{121}$ The question then is what to make of this elegant description of malpractice verdicts. The ABF's conclusion is that the data show that the malpractice system is not a lottery since patterns do occur. ${ }^{122}$

Some preliminary findings from our own ongoing study of malpractice litigation in the state of North Carolina provide further insight into the nature of the empirical issues raised above. As part of the study, we are examining in detail the court records for all medical malpractice cases filed in the state between June 1984 and July 1987. The final data set will total approximately 950 cases. We currently estimate that about 7 percent of the sample, or about sixty cases, were tried to verdict by a jury. At present we have data bearing on forty-seven cases, which we believe to be representative of the total trial group. ${ }^{123}$ Of the forty-seven cases, there have been ten plaintiff victories, establishing a plaintiff success rate of approximately 21 percent. In the cases where plaintiffs prevailed, one resulted in an award of $\$ 750,000$ and another in an award of over $\$ 300,000$; however, in the remaining cases the awards ranged between $\$ 0$ and $\$ 41,000$, with an average of $\$ 15,900$.

At first blush, these data suggest that North Carolina juries cannot be characterized as being either pro-plaintiff or consistently extravagant in their awards when they do find medical professionals liable. A closer examination of some of the characteristics of the North Carolina cases reveals some interesting findings. First, in the two cases resulting in large plaintiff's verdicts, the defendant's negligence appears reasonably clear, indicating that the cases

117. S. Daniels \& I. ANDrEws, supra note 95, at 14.

118. Id. at 15-17 (lable 5) (variables based upon severity of injury, cause of injury, and class of injury).

119. For example, Virginia recently enacted legislation providing a no-fault recovery for certain children born with neurological problems. VA. CoDE ANN. $\$$ 38.2-5000-5021 (1986 \& Supp. 1989).

120. S. Dantels \& 1 . ANDrews, supra note 95, at 12 (Table 5).

121. Id. at $22-25$

122. Id. at 23 .

123. At the time of our initial rescarch, approximately $15 \%$ of the cases reviewed were still pending. Clearly, a percentage of these cases will ultimately be tried. Since there may be significant variation in the proportion and indecd type of cases that were still pending, any analysis is necessarily preliminary. Because all malpractice cases are being reviewed, there is no bias attributable to sampling methods. 
probably went to trial over the amount of damages. ${ }^{124}$ Second, a surprisingly large number of cases were minor disputes. For example, five of the fortyseven trial cases involved dentists rather than physicians, a proportion significantly higher than dental cases in the total group of litigated cases. Also, three of the trial cases, while litigated as malpractice cases, could be categorized as slip and fall cases because they involved injuries sustained from falls from examination tables. Another of the cases, while also litigated as a malpractice case, actually involved a claim that certain autopsy procedures carried out by a pathologist had not been authorized by a deceased child's mother. Between ten and twelve of the cases could arguably be considered trivial or possibly non-meritorious suits given the nature of the alleged injuries. ${ }^{125}$

\section{B. Conceptual and Methodological Insights}

Given the various studies described above along with a few reflections from our ongoing research, what observations can fairly be drawn concerning the present state of the research effort? Based on the above studies, there is little support for the contention that juries in malpractice cases are proplaintiff and consistently inclined to award large sums of money to prevailing plaintiffs; indeed, it is possible to argue just the opposite, namely that juries are pro-defendant and often conservative in awarding damages. In truth, however, even this limited conclusion is questionable for several reasons.

First, the studies and our own work clearly indicate that trial cases are, as a whole, not a typical subset of malpractice cases. Whether there is a constant selection bias is less clear. The large variability across jurisdictions described by Daniels and Andrews underscores the point as well. The North Carolina results present a different picture of the selection bias than did Danzon's pioneering work. Whereas Danzon found that complex cases of uncertain liability or potentially large damages were disproportionately tried, our North Carolina observations reveal a different trial selection-one that is biased towards the selection of minor, indeed perhaps trivial, cases along with cases of clear liability where the parties are asking the jury to resolve disagreements over damages. Given the Rand study, it seems apparent that a more likely explanation is that the nature of those malpractice cases being tried may well change over time and may well vary between jurisdictions. Thus, a central task is to explore the nature of the selection bias further and to account for sources of variations.

The concern with selection bias also serves to underscore the importance of settlement. Without a comparison against the settlement patterns in the different jurisdictions, it is not possible to assess the workings of the system

124. One involved a dosage of chemotherapy drugs that was ten times the recommended dose; the other involved an eventual death resulting from the insertion of an anesthesia tube into the trachea rather than the esophagus on two successive but separate operations.

125. For example, one court file in a smaller community contains a rather remarkable letter from the plaintiff"s lawyer to the judge apologizing for taking the case to trial and blaming a "difficult" client. Other files clearly involve only claims of emotional damage or minor injuries that, on surface reading of the file, suggest that liability would be difficult to prove. 
properly. Taking cognizance of the trial selection bias and its changing character confirms the need to analyze the settlement process in its totality. Studies of jury verdicts that ignore comparative data on the other legal claims that did not go to trial are misleading because there is no way of determining how typical the trial cases are. Individual jurisdictions have their own legal cultures and other exigencies that affect settlement patterns, and, therefore, the kinds of cases that go to trial. Furthermore, these patterns change over time. Some attempts have been made to gather additional data from verdict reporters or insurers' files to control statistically some of the potential differences over time or across jurisdictions by means of regression analyses. The difficulty with this approach is that these additional data are often incomplete, provide information only about gross characteristics of cases, and give no insights into the processes that led to the jury verdict. This discussion thus brings us to a second major methodological issue, namely the danger of studying only verdict outcomes.

One problem with focusing on jury verdicts is the potential for overlooking the importance of posttrial modifications of the awards through other litigation means. While a large verdict itself may have an impact on other cases, it is clear that the litigation system provides numerous means by which jury verdicts can be modified. Most notably, the trial court has significant power in this regard, having the ability to: (1) grant a judgment in favor of the defendant despite the jury's decision; (2) order a new trial; or (3) require the plaintiff to accept a reduction in the amount awarded by the jury. In addition, the defendant may appeal and may then obtain relief of some sort. Finally, the parties may voluntarily agree to a settlement after trial in order to avoid the uncertainty of the appellate process. ${ }^{126}$ Taken collectively, this array of post-verdict adjusting mechanisms potentially constitutes a significant limitation on aberrant juries.

Until recently, this posttrial period was one of the least studied aspects of the procedural system. Two recent reports, however-both of which collected data on medical malpractice verdicts-have at least begun a serious consideration of posttrial adjustments. In the first study, Broder conducted a survey to determine the ultimate outcomes in cases where the jury initially awarded over $\$ 1.0$ million in damages. ${ }^{127}$ She concluded that in malpractice cases, the average large verdict was reduced by 27 percent during the posttrial

126. Indeed, the parties may have a pretrial settlement agreement that results in a reduction or increase of a jury's award. Such high-low agreements set the outside bounds of a flexible settlement. If the jury comes in with a verdict outside the upper range, the plaintiff has agreed to accept the "high." Similarly, if the jury comes in with a defendant's verdict, the plaintiff still obtains the "low."

127. Broder, Chararteristics of Million Dollar fwards: Jury l'erdicts and Final Disbursements, 11 Just. Sys. J. 349 (1986). The entire sample consisted of 537 cases constituting all known cases over a twoyear period between 1982 and 1983 . Information was returned on 472 cases, which was found to be usable in 362 cases. Of this group, 198 cases $(55 \%)$ had been finally terminated, while 164 cases $(45 \%)$ were still on appeal. Medical malpractice cases constituted approximately $20 \%$ of the sample. The report does not set forth whether the closure rate for malpractice cases varied from other categories of cases, nor does it report the means of termination (trial court adjustment, appeal, or voluntary settement). 
process. This percentage was typical of that found in other types of cases. ${ }^{12 x}$ Elsewhere in the report, Broder stated that as among different types of defendants (business, government, individuals, health care facilities, and utilities), health care facilities-the typical medical malpractice defendanthad the highest average awards after all posttrial adjustments were considered. ${ }^{129}$ Also, for all types of cases, the reductions were proportionally greater in those cases in which plaintiffs suffered less rather than more severe injuries. ${ }^{130}$

A Rand study conducted by Shanley and Peterson involving a larger sample also confirmed the fact that posttrial adjustments are potentially significant. ${ }^{31}$ This study showed that, overall, 80 percent of jury verdicts remained unchanged after trial. The researchers estimated that for medical malpractice cases, the average final amount paid was 67 percent of the original verdict; in other words, the average reduction for jury verdict awards in malpractice cases was 33 percent. ${ }^{132}$ It is important to observe that the percentage of reductions varied substantially according to the size of the original verdict. For verdicts involving $\$ 100,000$ or less, the average reduction was approximately 9 percent. ${ }^{133}$ For cases in the range from $\$ 100,000$ to $\$ 1.0$ million, the average reduction was 20 percent. For the few cases with an initial award over $\$ 1.0$ million, the average reduction was 39 percent. ${ }^{134}$ If these results are confirmed in subsequent studies, they would tend to suggest that the public concern with runaway juries might be effectively handled by the existing system.

There are substantial problems in interpreting the meaning of the two verdict adjustment surveys. Broder's statistics were based only on closed cases, constituting only a small proportion of an already limited sample. Similarly, Shanley and Peterson's study obtained data on only about half of the large verdicts in their sample. If the reduction ratios for cases taking longer to close were significantly different than those resolved sooner, the

\footnotetext{
128. Id. at 355 .

129. Id. at 354-55.

130. Id. at $356-57$

131. M. Shanley \& M. Peterson, Postrrial Adjustments to Jury Awards (1987). The researchers used a stratified random sampling plan dividing cases by size of jury verdict and by court to identify 880 cases for review out of a total universe of jury trials consisting of 3214 cases from federal and state courts located in either Cook County, Ill., San Francisco County, Cal.. or "other courts" in California. For the selected cases, survey forms were mailed to the attorneys involved in the trial seeking: (1) confirmation of the jury's verdict; and (2) information on posttrial adjustments. The response rate was approximately $60 \%$ and provided information on 621 closed cases. The data on the sampled closed cases were then used to estimate adjustment percentages for the entire universe of 3214 cases.

132. Id. at 27, 45. The estimates were based upon data received from posttrial adjustment information obtained from 37 closed medical malpractice cases. This information was then used to estimate post-adjustment ratios for the 76 malpractice cases in the total trial database of 3214 cases.

133. Id. at 45 (showing that average jury award of $\$ 43,000$ resulted in an average payment of $\$ 39,000$, constituting approximately $91 \%$ of the initial amount).

134. Id. This percentage was based on information from only six of twelve cases in the sample. The remaining cases in the sample consisted primarily of open cases, as the authors noted that large verdicts remained open substantially longer than smaller verdicts due in part to the length of the appellate process. Id. at 24-25.
} 
final figures might lead one to different conclusions about the posttrial system. The statistical summaries for both studies utilized averages, a summary statistic that, as already noted, could obscure skewed distributions. Furthermore, in neither study were the data disaggregated as to the specific mechanism of posttrial adjustment (trial or appellate court adjustment or voluntary settlement between the parties). As with jury verdicts themselves, then, empirical data on posttrial verdict adjustments are incomplete, and more detail on the adjustment process-and its impact on the overall dynamic of the settlement process-is required.

While the data provide important insights into the jury's performance, it is not possible without further information to make a definitive assessment of the jury's role. Indeed, one could argue that the high success level and high damages in the labor and delivery OB-GYN cases found by Daniels and Andrews raise a concern with this high profile area of malpractice litigation. Furthermore, because verdict reporters provide no information on the processes by which the outcomes were produced, no conclusions about the quality of the verdicts can be drawn.

Second, without some means of assessing whether the results in specific cases were appropriate, analysis of the juries' competence is not possible. Daniels and Andrews defined success as the plaintiff winning $\$ 1$. This definition is too one-dimensional to permit a proper evaluation of the juries' role. In order to fully comprehend the juries' performance, the result-the verdict-must be compared normatively to some appropriate standard. Zero verdicts may be errors. More importantly, a nominal plaintiff's victory may indeed reflect an award well below the plaintiff's anticipated recovery. In short, in assessing jury competence, it is as important to compare the amount of damages awarded with the anticipated results as it is to note whether the plaintiff received the verdict.

Consider for a moment a hypothetical example of a study of jury verdicts in a jurisdiction where one could be confident that basic settlement dynamics had not changed between time period $A$ and time period $B$. That is, juries were hearing the same kinds of cases. Assume further, that in comparison to time $A$, juries at time $B$ found in favor of the plaintiff more often and gave larger damage awards. Although one hypothesis to explain the result is that juries became more favorable to plaintiffs, we can generate a host of alternative hypotheses. A listing of a few of these competing hypotheses will suffice to make the point. Alternative Hypothesis 1: Changes in substantive or procedural law tipped the scales in favor of plaintiffs. ${ }^{135}$ Alternative Hypothesis 2: Members of the plaintiff bar improved in their ability to litigate cases by becoming specialists, improving the number and quality of theories of negligence, finding the right kinds of expert witnesses, and developing more effective modes of presenting their cases to the jury. Alternative

135. For example, analyses containcd in both Danzon, supra note 96 , and in the Rand studies, see. e.g., M. Petrerson, Civir. Juries, supra note 108, at 16-19, indicate that changes from contributory to comparative negligence standards had a significant impact on verdicts. 
Hypothesis 3: Actual economic losses suffered by the plaintiff increased due to rapidly increasing costs of corrective and palliative care and, in cases of very serious injury, increased life expectancy due to improved medical technology. These alternative explanations, none of which are necessarily exclusive of the others, are all plausible. Nevertheless, they would not be contained in the insurers' file data utilized by Danzon or in the verdict reporters utilized by Rand and the $\mathrm{ABF}$ researchers, or, it should be added, in the court files from which we derived our research data.

There are ways to obtain empirical data bearing on the various hypotheses, all of which require case by case analysis and then aggregation over cases. Lawyers can be interviewed and their files examined to determine the degree of similarity of cases that are tried versus settled. Systematic attempts can be made to observe trials and interview jurors about their decisionmaking processes. Estimates of the actual quantum of economic damages in a case can be determined by independent experts and compared to the jury decision. ${ }^{136}$ It is also possible to have the presiding trial judge make an independent estimate of the issues of liability and damages before the jury returns and compare that estimate against the jury decision. ${ }^{137}$ Various forms of simulation experiments could be undertaken in which the jury deliberation process is recorded and examined directly. ${ }^{138}$ None of these methods is without its problems with respect to the drawing of valid causal inferences. Ideally, multiple methods and sources of data should be used to shed light on the issue; the strengths of one approach might offset the weaknesses of the other. Such a research agenda is neither easy to undertake nor cheap. Nevertheless, as the critique of studies relying solely on jury verdicts makes clear, valid conclusions about jury performance cannot otherwise be made.

\section{V}

\section{Conclusion}

It is always harder to hit a moving target than a stationary one, and the litigation system is a dynamic process. The rules controlling the process change regularly; changes in substantive law interact with the procedural rules to vary litigation tactics; attorney customs and negotiation methods change regularly as well. It should not surprise us, therefore, that research into the process fails to provide answers to the most current questions.

136. P. Danzon, supra note $1 \mathrm{I}$, in fact utilized this approach for malpractice cases.

137. H. Kalven \& H. Zeisel, The American Jury (1966) (criminal juries), and Kalven. The Dignit) of the Civil Jury, 50 VA. L. REv. 1055 (1964) (civil juries), effectively utilized this approach.

138. The types of simulation include shadow juries, presentation of videotapes of actual trials, and isolating simulations that vary in the degree of verisimilitude to the trial process but have the advantage of allowing the researcher to test the effect of key variables against control conditions. $V$. Hans \& N. Vidmar, Judginc the JuRy (1986). For a review of various methods of empirical research relating to the jury, see $R$. MacCoun, Getring Inside the Black Box: Toward a Better Understanding of Civil Jury Behavior (1987). 
The process is not only dynamic, but complex. It is fair to say that we have only a most general understanding of the significance of many key litigation variables-including the role of the jury and the experience level of the attorneys-and their impact on the resolution of the ordinary case. The challenges for the empirical researcher are many. Hopefully, this article has provided some benefit by articulating some of the many questions generated by the present system. The greater challenge, of course, is going forward and seeking some of the answers. 
